Accounts of Nature and the Nature of Accounts: Critical reflections on environmental accounting and propositions for ecologically informed accounting

\author{
Shona Russell \\ School of Management, University of St Andrews, \\ St Andrews, Scotland \\ shona.russell@st-andrews.ac.uk
}

\author{
Markus J. Milne \\ College of Business \& Law, University of Canterbury, \\ Christchurch, New Zealand \\ markus.milne@canterbury.ac.nz
}

and

\title{
Colin Dey
}

Division of Accounting \& Finance, Stirling Management School, University of Stirling, Scotland

colin.dey@stir.ac.uk

\section{Acknowledgements:}

Thank you to the authors and reviewers for contributions to this special issue. Thank you to Jan Bebbington and Janis Russell for providing comments on earlier drafts. We also appreciate the continued support from Professors Guthrie and Parker, and wish to thank James Guthrie for arranging the review of this paper. Special thanks also to all those that participated in the 'Ecological Accounts' events in 2014 and 2015 held at the Universities of St. Andrews and Leicester that formed part of the journey. 


\title{
Accounts of Nature and the Nature of Accounts: Critical reflections on environmental accounting and propositions for ecologically informed accounting
}

\begin{abstract}
Purpose: This paper reviews and synthesises academic research in environmental accounting and demonstrates its shortcomings. It provokes scholars to rethink their conceptions of 'accounts' and 'nature', and alongside others in this AAAJ special issue, provides the basis for an agenda for theoretical and empirical research that begins to 'ecologise' accounting.

Design/methodology/approach: Utilising a wide range of thought from accounting, geography, sociology, political ecology, nature writing and social activism, the paper provides an analysis and critique of key themes associated with 40 years research in environmental accounting. It then considers how that broad base of work in social science, particularly pragmatic sociology (e.g. Latour, Boltanksi and Thévenot), could contribute to reimagining an ecologically informed accounting.
\end{abstract}

Findings: Environmental accounting research overwhelmingly focuses on economic entities and their inputs and outputs. Conceptually, an 'information throughput' model dominates. There is little or no environment in environmental accounting, and certainly no ecology. The papers in this $A A A J$ special issue contribute to these themes, and alongside social science literature, indicate significant opportunities for research to begin to overcome them.

Research Implications: This paper outlines and encourages the advancement of ecological accounts and accountabilities drawing on conceptual resources across social sciences, arts and humanities. It identifies areas for research to develop its interdisciplinary potential to contribute to ecological sustainability and social justice.

Originality: How to 'ecologise' accounting and conceptualise human and non-human entities has received little attention in accounting research. This paper and $A A A J$ special issue provides empirical, practical and theoretical material to advance further work.

Keywords: counter accounts, ecological accounts, environmental accounting, humannature, nature, non-human, pragmatic sociology, 'orders of worth', pluralism, sustainability.

Paper type: Research paper 
Cultures that see nature as a living being tend to carefully circumscribe the range of human intervention, because a hostile response is to be expected when a critical threshold has been passed. 'Environment' has nothing in common with this view: through the modernist eyes of such a concept, the limits imposed by nature appear merely as physical constraints on human survival. To call traditional economies 'ecological' is often to neglect that basic difference.

(Sachs, 1999, p. 67)

When we try to pick out anything by itself we find that it is bound fast by a thousand invisible cords that cannot be broken, to everything in the universe.

(John Muir, 1869)

\section{Introduction}

Human activity is recognised to be a major driver in global environmental change (Rockström et al., 2009; Steffen et al., 2015). Suggestions that we are now living in 'the Anthropocene'[1] lead to questions about how to develop within a safe and just space (Dearing et al., 2014; Waters et al., 2016) and the contribution social science, including accounting, can make to supporting ecological sustainability and social justice (Bebbington and Larrinaga, 2014; Bebbington and Thomson, 2013; Birkin et al., 2005; Brown et al., 2015; Dey and Russell, 2014; Fazey et al., 2017; Hackmann and St Clair, 2012; Hopwood, 2009; Milne and Gray, 2013). Intertwined within such efforts are various conceptualisations of human-nature relations that are themselves mediated by institutions, structures and practices (Castree and Braun, 2001; Castree, 2013; Gibbs, 2009), of which accounting is one example [2].

Why and how to account for, 'nature', 'environment' and 'ecology' has been debated within accounting scholarship. Early work warned against the harmful effects of accounting and accountants' involvement in attempts to undertake forms of accounting for the environment (e.g. Maunders and Burritt, 1991; Hines, 1988; 1991; Gray, 1992; Cooper, 1992; Milne, 1996a, 1996b; 2007). More recently scholars have examined, and contributed to, the design and implementation of calculative practices to take account of ecological issues and considered the implications for accountability (Bebbington, et al. 2001; Birkin, 2003; Egan, 2014; Hazelton, 2013; Samkin, et al. 2014; Tello et al., 2016). Questions of which 'accounts' and which 'natures' are subject to analysis in accounting scholarship have permeated this body of work in both critiques of environmental accounting (see, Cooper, 1992; Hines, 1991) and calls to examine and develop new accountings for socio-ecological change (Brown et al., 2015; Gray et al., 2014). The extent to which this may (not) have been achieved, or could do so in the future, prompts us to ask 'why are things like that?' (Armstrong, 2017) and what assumptions frame the accounting scholarship that concern ecological issues? How might other theoretical frames or interdisciplinary approaches contribute to alternatives?[3]

This paper examines trends in the area of environmental accounting scholarship. It explores the limits and possibilities of future scholarship by taking broad notions of 'account' and 'account giving' (e.g., Boltanski and Thévenot, 2006; Orbuch, 1997; Scott and Lyman, 1968) recognising various conceptions of nature, natural and nature-society relations (e.g. Castree, 
2005; 2013). It is argued that an 'information throughput' model dominates much environmental accounting research, with a continued focus on economic entities and their environmental inputs and outputs. A model and focus, we argue, is unlikely to contribute to the realisation of ecological sustainability and social justice - normative aspirations that motivate much accounting research. Arguing for future work to 'ecologise' accounting, the paper sets out the 'orders of worth' framing (Boltanski and Thévenot, 2006; Latour, 1998; Blok, 2013) as a potentially influential way of enhancing scholarship concerning accounting and socio-ecological change before outlining several other areas for future collaborative research with conservation scientists, other social scientists and arts and humanities scholars (Simmons, 2013). Complementing this paper, the rest of the papers accepted for this $A A A J$ special issue investigate the impacts of accounting innovations and accountability practices on efforts to conserve and protect socio-ecological systems (Cuckston, 2017; Ferreira, 2017; Gaia and Jones, 2017; Sullivan and Hannis, 2017) and examine forms of account-giving that might increase the visibility of our socio-ecological interdependencies (Feger and Mermet, 2017; Laine and Vinnari, 2017; Lanka, Khadaroo and Böhm, 2017). Taken together, they contribute to theoretical and empirical understanding of accounting in the organisation and economisation of human-nature relations (Chua, 2011; Gendron, 2015; Miller and Power, 2013; Parker, 2011).

To summarise, the rest of the paper is structured as follows: in section two, the motivation for the $A A A J$ special issue is introduced. In section three, each of the papers is briefly described to foreground a review of key trends in environmental accounting scholarship over the last four decades in section four. In section five, propositions of ways to 'ecologise accounting' are outlined with reference to the work of Boltanski and Thévenot (2006) and Latour (1998) concerning 'orders of worth'. Finally, in the sixth section we offer several propositions that could guide future research and engagement in this field of study.

\section{Ecological Accounts: Introducing the special issue}

The term 'ecological accounts' may well evoke thoughts of efforts to integrate externalities into accounting and reporting practice as a way of reframing the responsibilities and accountabilities of organisational entities (Birkin, 2003). Equally, though, the term could be associated with accounts of forests (Atkins and Thomson, 2014), rivers (Dey and Russell, 2014), lakes (WET, 2015) or blanket bogs[4] (Cuckston, 2017). How might this broad terrain of scholarship be understood? What other empirical sites, theoretical perspectives and disciplinary approaches could further enhance the aims of critical, interdisciplinary and social and environmental accounting projects?

This special issue welcomed work that explored, examined and critiqued efforts to make (in)visible the impacts and interconnections of humans, their organisations, and non-human worlds[5]. The scope of the call for papers was prompted by a curiosity about the parameters 
of environmental accounting and the types of 'accounts' and 'natures' that are deemed worthy of research, and the implications of broadening interdisciplinary enquiries for the conceptualisation of entities, accountabilities and accounts themselves. Such curiosity is best illustrated with a brief foray into the world of nature writing and environmental campaigns in order to problematise notions of accounts and natures.

\section{Nature writing}

Recently, Craig Potton, famed New Zealand photographer, documentary maker, publisher, author and conservationist, published an account of a journey through the Southern Alps of New Zealand. So far so good (2016), recalls a three-month trek by Potton and three companions over mountain passes, through snow fields and forests, and up river beds seeking shelter under rocks, under canvas, and in small mountain huts. The account is not a dry, systematic, numerical record of dates, days travelled, kilometres covered, weights carried, or lists of gear taken and foods consumed. There are no asset registers, no balance sheets or profit statements, but one is left in no doubt that this is a compelling narrative of strategic and operational planning, adversities faced and difficulties overcome. This is an organisational account, a significant quarterly account in fact, of four humans who intimately interact with each other and with their natural environment for three months. Plans are formed, actions determined, and then thwarted and plans reformed. Potton reveals an evocative account of the relationships between the ever-changing material existence in which he is suspended the land and all its forms, the vistas, the weather, the birdlife, the pond life, dwindling food supplies, his companions, and his inner worlds of thought and consciousness. Holed up in huts for days because of storms and flooded rivers, facing avalanche prone slopes, rationing food, and seeking warmth, the four are regularly reduced to the simplest of Maslow's needs. Long before this account ends, one is left in no doubt of the 'value creation story' that it is. Potton's early adult life is part-forged in this mountain crucible, and he is forever shaped by these experiences: the land, the creatures, the weather, his hunger, his companions, they are seared into his memory such that the account can be recalled 30 years later.

Now this is no ordinary account of intimate relations between humans and the non-human world, about sentiments and life, and the biotic and non-biotic, but neither is it unique. We might have easily chosen others to make our point such as John Muir's Travels in Alaska (1915), or his My First Summer in the Sierra (1911); or Charlie Douglas' observations made during a lifetime in New Zealand's Alps as an explorer/surveyor (Pascoe, 1957); or perhaps more local accounts of the intimate relations of Thoreau, the Concord woods and Walden pond (Thoreau, 1854); or Leopold's Sand Country Almanac (Leopold, 1949); or John ListerKaye's Song of the Rolling Earth (2003) in which he provides first-hand accounts of conservation and ecological restoration near Inverness; or perhaps Helen Macdonald's (2014) award-winning intimate account of her relationship with a goshawk in $\mathrm{H}$ is for Hawk. 
What these accounts also have in common is that they are most likely regarded by the vast majority of accounting scholars as not 'proper' accounts for study. We suspect that even a great many of our 'interdisciplinary' accounting colleagues will baulk at the thought that such accounts might be legitimate objects of study. Indeed, we note one colleague who disparagingly noted that 'story' could so easily be substituted for 'account', which consequently rendered it suspect for study. Why might this be so? And what are the consequences of rejecting such possibilities? What is lost by ruling out these 'accounts' (or stories) within our scholarship? Are we bound to study only economic entities and their expressed (and counter expressed) relations to the natural world? And, if so, what are the implications of such conceptions for accounting, accountability and nature?

Perhaps we could have chosen Nan Shepherd's experiences of the Cairngorm mountains of Scotland (Shepherd, 1934; 1977), or Kathleen Jamie's (2012) Sightlines where she troubles a "foreshortened definition of 'nature'" noting nature is not always out there. It is in our bodies as well as in far off lands or seas. "It's not all primroses and otters" (p. 24), nature can be found in cancerous cells[6]. One is reminded, then, of the interconnectedness of human and non-human worlds, the value of experience and learning from others including non-humans (Hines, 1991; Waterton, 2003; Whatmore and Landström, 2011) and the need to reflect on subjects through ecological, social, historical as well as financial lenses (Lilley, 2013).

\section{Environmental campaigns}

Debates about the legitimacy of accounts extend beyond the realm of research practice and acceptable units of analysis and data. They reach into questions of knowledge controversies, decision-making, accountabilities, and ways of knowing humans and non-humans (Barry 2013; Whatmore 2013). Our second foray into less chartered waters of environmental accounting, namely social movements, is to consider how accounts of nature are defined and understood. Box 1 presents the observations - as an account or product of research enquiry (Orbuch, 1997) - of an event organised as part of a contested arena concerning water management and local democracy in Canterbury, New Zealand [7].

[Box 1 about here]

In the first instance, one would ask: is this cairn an account worthy of analysis? Does it meet (un)stated criteria of what constitutes legitimate accounts? It does not include numerical information about the number of stones, their origins, the labour costs or hours associated with the creation of the cairn. It is not rebuilt each year in accordance with the annual reporting cycle of those organisations with responsibilities for water management or the users 
of the region's water or the term of each of the environment commissioners. Yet, it does convey the socio-materiality of rivers and concerns for democracy when accompanied by the plaque. What about the speech from poet Brian Turner? Would this be deemed a legitimate account? The speech would likely qualify and be quoted in a detailed case study of social movements (e.g. Laine and Vinnari, 2017; Thomson et al., 2015). Both were created in 2010 and are visible today: the cairn comprises river stones and stands in the City's square; the speech is accessible via the campaign's website for those that wish to look. The cairn, the speeches and information about the associated campaign are part of a contested arena concerning water resource management and changes in the way that governance was enacted (Dey and Russell, 2014; Thomson et al., 2015). Arguably, both are story-like conceptions that provide insights into human experience of rivers and democracy. They can be seen as the object of enquiry with analysis on the construction and form of the cairn and the speech; they may be seen as the means through which to understand the concerns of those involved in the campaign (Orbuch, 1997).

The accounts given may be seen as examples of pluralism in democratic societies (Brown, 2009; Brown et al., 2015) in contrast to those given and received through formal opportunities to participate in decision-making related to water or in accordance with voluntary initiatives (Hazelton, 2013). The 'natures' presented through socio-material arrangements of rock, metal and text suggest a dissatisfaction with human activities - in this case dairy production - that impact upon freshwater ecosystems. Like the nature writing discussed above, this event, and the associated accounts, illustrate the diversity of ways in which narratives of experience with external natures are interwoven with insights into the nature in our heads and bodies. They generate a sensitivity to the particular human-nature relations produced and illustrate their contingency in space and time (Cronon, 1995).

Nature writing, the cairn and the speech attempt to connect humans and non-human worlds. They prompt questions about which accounts matter when? And to whom? What natures may be conserved, exploited or left alone not worthy of attention? What accountabilities are performed? (Carolan, 2006; Castree, 2013; Thomson et al., 2014). Recognising that institutions, structures, practices and epistemic communities, including accounting practitioners and academics, mediate understandings of human-nature relations (Castree, 2013), attending to different types of accounts could provide further insights into exploitative capitalist, gender and colonial relations (Birkin, 1996; Cooper, 1992; Cooper and Senkl 2016; Ginn and Demeritt, 2009; Hines, 1991). In sharing them, we wish to provoke questioning of conventions and core concepts of environmental accounting (Everett, 2004). The papers published in this special issue go some way to answering these questions through a variety of studies that are introduced in the next section but further research is merited as we outline in section six. 


\section{Introducing the articles in this Special Issue}

Informed by fields of environmental humanities, conservation science, critical management studies, political science, geography, science and technology studies, the papers examine and illustrate a variety of ways in which accounting and (counter) accounting contribute to ordering and production of human-nature relations. This $A A A J$ special issue includes conceptual papers drawing on extant literature and empirical case studies from the United Kingdom, India, and Finland that draw upon documentary analysis and interviews. Collectively they highlight the role accounts and accounting practice plays in producing and ordering human-nature relations in relation to topics of conservation and production and consumption of food in terrestrial spaces.

Sullivan and Hannis (2017) in "'Mathematics maybe, but not money'..." explore the philosophical foundations of ecological accounting as a numbering practice that produces standardised, monetary values for nature. The authors emphasise the inherent performativity of calculative practices in enrolling, shaping and legitimising specific social and economic relationships with nature. Drawing on analysis of policy documents pertaining to the UK's natural capital and biodiversity offsetting schemes, Sullivan and Hannis (2017, p. xxx) assert that "using money as a measure of nature's value(s) may effectively 'miss the point' and thereby trivialise and devalue both nature and human relationships with natures-beyond-thehuman". They conclude with an exploration of fractals and consideration of how geometrical mathematics could offer an alternative for ecological accounting. They argue that the properties of fractal representations may be seen to embody emotional and sensual elements, which in turn may help to foster values of harmony and humility as well as a deeper ethic of care and resilience.

Laine and Vinnari (2017) examine Finnish activists' unauthorised, covert filming of the conditions in which pigs and chickens were being kept as visual counter accounts drawing on a longitudinal case study. The authors extend Thomson et al.'s (2015) dynamic conflict arena framework by integrating it with concepts from Laclau and Mouffe's (1985) work on discourse theory. Meat production is framed as a key discursive signifier or 'nodal point' within the discourse of animal production and consumption. Their analysis illustrates the success of the activist campaign in challenging both the regulation of the meat industry and the fundamental legitimacy of meat production and consumption, particularly by attracting mainstream media coverage. However, the authors also highlight how the campaign provided dominant institutions with their own discursive ammunition, to attack not only the campaign but the campaigners themselves. In doing so, they suggest that the discursive role of counter accounts encompasses not only the definition and construction of meaning, but also of identity. 
Feger and Mermet (2017) propose an interdisciplinary research agenda to support collective action to resolve ecological challenges, arguing that valuable insights from critical accounting could contribute to the sustainable management of ecosystems. The authors outline the complex organisational, institutional and political realities in which conservation science and practice is embedded and in which accountabilities are enacted. They remind us context matters and that context extends beyond the parameter of one economic entity. Taking account of these complex settings and the relative responsibilities of specific actors is imperative when justifying why certain organisations or practices become legitimate objects of analysis, and considering how accounting could contribute to collective action that addresses ecological challenges. This paper makes an important contribution in examining the similarities and differences between calculative practices and the use of information systems in accounting and conservation science. Read alongside the rest of this $A A A J$ special issue, this paper will likely enhance theoretical and empirical understanding of accounting for the management of ecosystems and establish promising collaborations between accounting and conservation science.

Cuckston (2017) proposes an 'ecology-centred' accounting responding to criticisms of fundamental problems associated with organisation-centred attempts to manage sustainability (Milne and Gray, 2013). Drawing on relevant concepts from geography, Cuckston (2017) explores what it means to conceptualise an ecological system - namely a peatland habitat in the upland moors of northern England - as an accounting entity. For him, existing scientific site classifications and associated forms of ecological monitoring are fundamentally enabling, in the sense that they can transform the conservation of biodiversity and restoration of the blanket bog into something that is thinkable and possible. Cuckston (2017, p. xxx) concludes by arguing that his findings demonstrate that ecology-centred accounts can effectively embody accounting's 'productive force' (Miller and Power, 2013), to create "conditions in which forms of organising of human and non-human actors into socioecological systems become thinkable and possible."

Ferreira (2017) examines the UK government's pilot scheme to create a nationwide market for biodiversity offsets. Drawing on documentary analysis and interviews with practitioners and regulators, Ferreira's (2017) case study focuses not only on how the scheme came into existence, but also how it later ceased after only two years. Conceptualising markets as a form of economic governance that depend for their stability upon an assemblage of discursive elements, he highlights the role of biodiversity accounting as a key component in rendering this domain governable. However, in the case of the pilot scheme, the use of such accounting was not sufficient for biodiversity offsets to become a fully tradeable commodity, because of the complicating influence of other elements within the assemblage. On the one hand, this was partly due to fundamental constraints of location and physical geography. At the same time, the success of the scheme also depended on the politics of this nascent market. 
Lanka et al. (2017, p. xxx) explore the impact of agroecological management on various aspects of biodiversity, and conceptualise their study as "an emancipatory counter account" drawing on narrative and testimony of smallholder coffee farmers in a co-operative in southern India[8]. Using Marxist labour theory of value to understand the value provided by biodiversity to the co-operative, they argue that they are better able to problematise the marginalised, subaltern status of the indigenous smallholding famers. From this perspective, the impact of agroecology is as much, or indeed more, about protecting the sustainability of livelihoods as it is of ecosystems. Lanka et al.'s (2017) analysis of socio-ecological change highlights the fundamental issue of scale as a characteristic, both in terms of (counter) accounts of biodiversity as well as in agroecology (Bland and Bell, 2007). At a field or farm level, agroecological practices successfully challenged and reformed dominant governance mechanisms surrounding coffee production, improved local biodiversity, and educated smallholders. However, it had much less impact at a broader system level on prevailing economic and environmental governance, and the extent to which counter accounts could contribute to such a reconfiguration remains to be seen.

Finally, Gaia and Jones (2017) present an analysis of narratives in biodiversity action plans, understood as an example of biodiversity reports. Informed by stakeholder theory and a communitarian approach to accountability, they (p. xxx) assert that biodiversity reporting "fosters stakeholder participation in the management of sustainability issues." Following content analysis of plans, Gaia and Jones (2017) find that instrumental values focusing on human welfare ecology and resource conservation dominate compared to those associated with intermediate or deep philosophical perspectives. In tracing the narratives and publication of plans over time, the orchestrating event (MacDonald and Corson, 2014) of the International Year of Biodiversity appears to have catalysed planning practice. For those wishing to follow the development and implementation of accounting and reporting practice, it is worth attending to the influence of such events and understanding how international events can shape local practices. This study provides one snapshot of the types of narratives of preparers (Bebbington et al., 2012) and could act as a foundation for further research examining the connection between narratives and management practices of local councils and other stakeholders.

We now trace the contours of past research in 'environmental accounting', complemented by further insights from the papers introduced in this AAAJ special issue. Much as Sachs's (1999) opening quote to our paper suggests, we anticipate it will become clear that there are fundamental limitations to the way in which 'environment' has been conceptualised in our accounting scholarship to date. 


\section{Towards Ecological Accounts and their Interdisciplinary Place}

Over the years, a considerable literature has built up in the field of 'social and environmental accounting'. Much of it has now been systematically (and unsystematically) reviewed. Good overviews can be found in Gray et al. (2014), Bebbington et al. (2014), and Gray and Guthrie (2007). Similarly, a number of extensive reviews of journal papers have appeared[9]. Coupled with these reviews, we can also highlight other collections dedicated to 'environmental accounting' including a number of other $A A A J$ special issues [10]. Taken together, these works indicate a considerable range of thought and practice in the field. The aim here, then, is not to rehash the detail, but rather stand back and pick out significant elements and trends, before again zooming out to place these developments in a yet broader disciplinary and interdisciplinary framework.

\section{Normative demands, full cost accounting, valuation and its contestation.}

Before the 1990s, academic accounting work that focused on the environment was largely normative; seeking to explore, develop and extend accounting systems so that traditional accounts could include environmental impacts beyond market transactions. The dominant theme was to identify, measure, count, and ultimately monetise 'environmental costs and benefits' and draw them into conventional organisational financial accounts, or propose comprehensive monetised accounts (for brief overviews see, Mathews, 1984; Gray et al., 1987; Milne, 2007)[11]. The 1990s saw a thin vein of this work continue. Milne (1991), for example, sought to explore the prospects for drawing on environmental economics and its non-market valuation techniques to augment management accounting systems. Herbohn (2005) reports on an experimental case to use such techniques in an Australian forestry enterprise. Gray (1992), also drawing on work in economics and notions of 'natural capital', explored the prospects for organisation level 'sustainability accounts'. And Bebbington et al. (2001) provide further experimental examples, while seeking to lay out an agenda for the accountancy profession to promote full cost accounting. Overall, though, this stream of thought on entity accounting capturing 'externalities' and 'full cost accounting' has dwindled.

Yet, the research area remains pertinent on at least two counts. First, valid objections still stand about the monetisation of non-financial environmental impacts, especially where these might be coupled to capitalising and appropriating 'common property resources' such as forests, lakes, rivers, and the atmosphere[12]. As Gray (1992, p. 416-417) was only too aware, there are "...profound dangers in trying to employ calculation in a world where... calculation can be identified as a root cause" and where it runs the risk of "...reinforcing analytic and scientistic solutions when, within a deep green context, one is attempting to do quite the opposite." A key concern raised in all manner of contexts where economics is seen to 'colonise' territory is that it crowds out alternative ways of determining values, decision outcomes, and even what becomes thinkable (see Hines, 1991; Cooper, 1992; Shearer, 2002; 
Milne 1996a; 1996b; Cooper and Senkl, 2016; more broadly see O'Neill and Spash, 2000; O'Neill et al., 2008; Fourcade, 2011; Sandel, 2012; Kallis et al., 2013; Roscoe, 2014). Critical concerns relate to both the technical issues of whether such approaches are valid and feasible (i.e. whether it can be done, and when and how), and the distributional, anti-democratic, moral and relational effects of doing so (i.e. whether it should be done, and if so, what are the consequences). Significantly, the cultural context in which monetisation occurs also matters: 'money', 'nature' and the acceptability of their coupling seem culturally (sociohistorically) determined and legitimised (Moody and Thévenot, 2000; Thévenot et al., 2000; Fourcade, 2011).

Secondly, capitalising and monetising the 'environment' appears a growing practice or, at the very least, it is being seriously promoted by some economists and conservationists alike (e.g. Sukhdev et al., 2010; Helm, 2015; Juniper, 2013). Notions of 'natural capital accounting', 'payments for ecosystem services' and variants abound (e.g. Natural Capital Coalition, 2017; KPMG, 2017; KPMG/ACCA, 2015; CIMA 2014; Trucost, 2017; Eftec, 2017). Arguably, natural capital within organisational practice has been given further stimulus with the advent of the Integrated Reporting Framework (IIRC, 2013) and its reference to natural capital as one of six capitals organisations draw on. Other initiatives include, for example, environmental impact bonds (Clark and Nicola, 2013)[13] and biodiversity banking and offsetting[14]. And while there is some enthusiasm for these initiatives, concerns persist about underlying accountability and governance problems associated with private capital (Balboa, 2016). Not all are excited at the prospect of the 'financialisation of nature' (e.g. Brockington and Duffy, 2010; 2011; Sullivan, 2014).

In this special issue, Sullivan and Hannis (2017) and Ferreira (2017) pick up on issues associated with the concept of natural capital, its enumeration and valuation. Sullivan and Hannis (2017), drawing on an exploration of the ontological and ethical assumptions embodied in these practices, illustrate how such methods depend largely upon linear arithmetical rationalities and metrological techniques. They further argue that the new visibilities created by such methods are often contested, instead of being a conduit for greater comparability, consensus and conservation. Consequently, they do not necessarily prevent further ecological damage and loss of biodiversity.

For his part, Ferreira (2017, p. xxx) demonstrates the limits of accounting practice in attempting to make biodiversity measureable and quantifiable: "when framed into a commodity, biodiversity does not easily 'travel'; its fungibility and exchangeability are circumscribed to a specific location." Nonetheless, Ferreira (2017) concludes by arguing that elements of the original assemblage do survive and may still re-emerge, but in other, more hybrid governance regimes. Using a particularly appropriate genetic metaphor, he emphasises the "recombinant nature of assemblages - how ideas, devices, people and non- 
human entities can circulate and impact the world" (p. xxx, emphasis added). Both papers enrich understanding of how accounting practices mediate of human-nature relations. There remains considerable potential to critically probe concepts like natural capital accounting, biodiversity offsets, nature bonds, etc. and how they do and do not spread and institutionalise, especially in the light of capitalist actors and other professional and government involvement.

\section{Non-financial accounting, accounts and reporting, assurance and 'end users'}

While monetised environmental accounts have not taken off, non-financial accounts or, more accurately, non-financial disclosures have. A linear periodic information model of accounting and accounts produced by economic entities for insiders and outsiders remains central to environmental accounting practice and scholarship. Concern exists with demonstrating (or otherwise) the economic decision usefulness of such information (i.e. for indicating efficiency to managers and value relevance for investors) or critically questioning the motives for it and/or its capacity to deliver accountability to stakeholders. Monetised economic transactions remain the disciplinary core of conventional accounting, accounts, auditing and accountability scholarship. 'Environmental accounting' scholarship overall, however, has not strayed far: in fact, it remains the non-financial variant[15].

Annual reports, and their underlying information generation systems, have expanded greatly over the past 40 years both in terms of additional narrative economic non-financial information (e.g. MD\&A, directors' reports, risk reports, CEO statements) and environmental (and social) non-financial information. Environmental management systems capture nonfinancial data on energy, carbon, water, waste materials and biodiversity impacts for example (e.g. Bansal and Roth, 2000; Delmas and Toffel, 2008; Darnall et al., 2010). Under management's discretion, this information finds its way in narrative and quantitative form into periodic external reports (e.g. Kolk et al., 2008; Rankin et al., 2011; Hahn et al., 2015; Russell and Lewis, 2014; Rimmel and Jonäll, 2013; Boiral, 2016). The underlying technologies and platforms by which the information is produced, disseminated and communicated is constantly evolving in terms of event and continuous reporting, in terms of audio/visual formats, private and oral reporting (e.g. Solomon and Solomon, 2006), press releases and other social media formats. Yet, while new elements emerge in 'environmental accounting' and new mechanisms arrive to deliver 'environmental reports' they constitute information production and dissemination by economic entities, and this dominates our scholarship.

Of course, this is not all that is studied as environmental accounting. The professional, social, and political context under which rules and regulations are developed to bring these practices into play, and how they change and are influenced overtime attracts attention (e.g. Power, 1997; Etzion and Ferraro, 2010; O'Dwyer, 2011; Humphrey et al., 2017). Likewise, there is a focus on the quality and veracity of the information produced and disseminated, and the 
(absence of) standards for its assurance (e.g. Gray, 2000; Owen et al., 2000; O'Dwyer and Owen, 2005; O'Dwyer et al., 2011). Work also focuses on the potential capacity of nonfinancial stakeholders to be influenced by the information produced (e.g. Dierkes and Antal, 1985; Tilt, 2007; Kuruppu and Milne, 2010; Lee and Sweeney, 2015) or to influence it (e.g. Tilt, 1994; Deegan and Blomquist, 2006). Concern also extends to whether sufficient platforms operate to overcome asymmetries of information and power to permit stakeholder democracy (e.g. Dierkes and Antal, 1986; Cooper and Owen, 2007; Unerman and Bennett, 2004). Even so, all such interest, even in those studies with a critical element, seems focused on the central organising tendencies of economic entities.

Under such a model the environment is framed as a series of inert, lifeless, fragmented inputs and outputs to and from a transformation engine to be run most efficiently and profitably (Gray, 1992; Bebbington and Gray, 1993; Milne, 1996b; Milne et al., 2009)[16]. Think of the content of the UNEP environmental/sustainability report benchmarking methodology (SustainAbility, 2006), the GRI G4 environmental disclosure items (GRI, 2014), or the business model/six capitals flow diagram in the Integrated Reporting framework (IIRC, 2013, pp. 1213), and one sees the environment/natural capital as little more than stocks and flows of energy and matter (resources) to be rearranged for economic purposes. Absent from such an approach is the notion of human activity taking place in a complex, living socio-bio-physical (ecological) context of interrelated systems. Dierkes and Preston's (1977, p.6, 14-15, our emphasis) early observations reveal just how limited organisational environmental accounts and reports will remain:

\footnotetext{
The nature and scope of environmental impacts varies so greatly among firms and types of economic activity that the search for a single set of analytical categories, measurement techniques, and decision-criteria for corporate social accounting reporting in this area seems almost certain to be fruitless... [The accounting system] confines itself to reporting companies' commitments (inputs)....as well as performance data (outputs) which includes for example, the levels of pollutant emissions and changes in these levels. Secondary external effects-for example, the consequences of pollution on the health of the surrounding community or the general ecological system - are excluded. Such effects, although of great importance, can only be dealt with seriously in extensive and sharply focused studies which, due to the reasons previously mentioned, cannot be integrated into a continuous and regular reporting system.
}

While 'monetised transactions' are no longer essential for the production and dissemination of environmental accounts, the limited organisational practice of regular periodic nonfinancial performance reporting and disclosure appears to have created a disciplinary anchor. As scholars, we have become boxed-in by extant organisational practice (Alvesson and Sandberg, 2014; Tregidga et al., 2015). Even when the focus changes to organisational entities with broader community and regional responsibilities (e.g. councils, government departments - see for example, Lodhia et al., 2012; Samkin and Schneider, 2010; Samkin et al., 2014) there is a reluctance to move beyond the organisational boundary. In some sense, there is no environment in 'environmental accounting' and there is certainly no ecology. 


\section{Counter-accounts, polyvocal accounts, and pluralism}

Breaking free of the limited yet dominant conception of environmental accounting arguably requires perspectives from outside of the accounting/economic/organisational framework (Gray and Laughlin 1991; Owen, 2007; 2008; Gray et al., 1997; Gray et al., 2009). To inject an understanding of human and non-human entities and their socio-bio-physical relationships into the scene, other voices, other experts, but also from communities and citizens, and perhaps our own inner voices are required. Calls for a broader more plural focus when it comes to accounts of human relations with the non-human world - call it ecology, nature, or the bio-physical context - come from many quarters (e.g. Latour 1998; 2004; Boltanski and Thévenot, 1991/2006; Thévenot et al., 2000; Vinnari and Dillard, 2016; Dey and Gibbon, 2014; Castree, 2013; Lehman, 2017; Sayers, 2016; Connolly and Cullen, 2017; Waistell, 2016). It is from broader perspectives, other articulations and justifications, drawing on various frames, from various cultures, in multiple media and formats that something is learned of the external effects of organisations and our own behaviours. It is from these that we learn something of how to change both ourselves and our relations (Dey, 2003; Gallhofer et al., 2006; Spence, 2009; Dey et al., 2011; Gray et al., 2014).

As Dey and Gibbon (2014, p. 109-111) illustrate, early alternative perspectives to organisational accounts came (e.g. Medawar, 1976), and continue to come, in the form of external and counter-accounts sometimes from activist campaigning, sometimes from investigative journalism, and sometimes from motivated academics[17]. Such accounts might vary from systematic attempts at performance reports to ad hoc partisan projects from NGOS and activists. Such accounts seek to expose invisibility, contradictions and inconsistencies, raise questions about integrity and legitimacy, and often hope to motivate political and policy action. Greenpeace New Zealand (1996), for example, released Pulp fiction: the environmental impact of the Tasman Pulp and Paper mill on the Tarawera River as a counter to Tasman Pulp and Paper's 1996 first corporate environmental report to illustrate the ongoing pollution (with dioxins and organochlorines) of the Tarawera River - a sacred body of water for local indigenous Māori[18]. Christian Aid's Behind the Mask (2004) targeted Shell in Nigeria, British American Tobacco in Kenya, and Coca Cola in India, highlighting polluted drinking water, loss of ground water for drinking and cropping, loss of food sources, chemical contamination and human poisoning, economic dependency and exploitation. Tregidga (2017) illustrates an activist counter report against Solid Energy's plans to open-cast coal mine on conservation land. In this instance, the activists inter alia produced a spoof corporate environmental report for which they were taken to court[19]. At issue are biodiversity impacts, climate change, and water pollution from mining waste[20].

Other perspectives can be gained from academic research that seeks to build a picture of organisational performance from multiple media sources. Ruffing (2007), for example, compares BP America's 2005 sustainability report with a series of articles which appeared in 
the Financial Times. In contrast to the organisation's report, the litany of safety and environmental events reported in the $F T$ point to a systemic culture of negligence, and arguably provide a prescient harbinger of the 2010 Gulf of Mexico disaster. Adams (2004) explores the 'gap' between what a company says about itself and what others know and report. Her analysis provides insights into how one is likely to learn more about the consequences and external (health and environmental) effects of organisational behaviour and corporate products (e.g. cancers, animal deaths) from sources outside the organisation. Endangering people and other life forms is not something organisations readily choose to report or, where they do, a particular tactic it seems is to report significant uncertainty as to the chain of causation and hence organisational responsibility for the effects.

More recent work has sought to draw on the metaphor of an 'arena' in which multiple voices and accounts are articulated, and in which different world views and frames are invoked as part of contestation (e.g. Georgakopoulos and Thomson, 2008; Thomson et al., 2015; Dey and Russell, 2014). Such a perspective recognises that a broad group of 'interests' 'message amplifiers' and influencers revolve around sites of contest. This approach changes the loci of accounts from periodic entity performance to incidents, events, or even future intended activities. Consequently, it may, in part at least, place the central focus on non-economic entities. In Dey and Russell (2014), for example, the arena is formed around the River Garry in Scotland. And in Laine and Vinnari (2017) in this special issue, the accounting entity becomes animals (pigs specifically) farmed for meat consumption, and the 'accounts' become digital film recordings by activists with an attendant focus on the moral concern of animal welfare[21].

Laine and Vinnari (2017) argue that the discursive role of counter accounts involves not only the definition and construction of meaning but also of that of identity, which is inextricably linked to processes of representation and perception, and therefore highly relevant to the dynamics and the outcome of discursive struggles. They illustrate that the way in which the animal rights campaigners' identity came to be defined can be seen as an example of what Laclau and Mouffe (1985) term 'radical negativity', in which meaning is constructed only by association with attributes that are absent. In this way, dominant social groups sought to portray the activists as lacking the integrity, judgement or skill-set of respected professionals or state authorities. The deep political divide created by this institutional response, together with the refusal of the activists themselves to engage directly with the meat industry or its regulators, is seen as an example of what Laclau (2005) terms an 'antagonistic frontier' between conflict arena participants. Laine and Vinnari (2017, p. xxx) conclude that "as a consequence of this polarisation, the counter accounts [...] managed to some extent to rearticulate the meaning of animal production [...] However, whether or not this will lead to more large-scale change remains an open empirical question". 
The (in)capacity of counter accounts to produce scale effects is also evident in Lanka et al.'s (2017) exploration of the relationship between ecosystems and the livelihoods of the smallholders. Moral concern about the restoration and preservation of biodiversity is coupled with that associated with financial benefits: from the savings gained from not buying chemical fertiliser, and from the increased yield and price from the (now organic) coffee beans. The case study reveals that the use of agroecological management was in many ways successful in challenging and reforming dominant governance mechanisms surrounding coffee production, in protecting and improving local biodiversity, and in empowering and educating smallholders. However, the outcome at a broader scale or system level had much less of an impact on prevailing economic and environmental governance. Lanka et al. (2017, p. xxx) conclude that "the emancipatory potential of an agroecological transformation can [only] be considered to be complete when [...] consumers and producers can be directly linked" - in other words, by nothing short of a revolution in food production and distribution.

In stepping away from a focus on accounts produced by economic entities, alternative and counter accounts come into view. For Laine and Vinnari (2017) and Lanka et al. (2017), these accounts are central to their analysis of food production and associated social movements. The papers illustrate how critiques or alternatives can be constrained by prevailing politics and economic governance. How then might we move beyond prevailing politics? is a revolution required? Or perhaps a reconfiguration of conceptualising accounts and humannature relations?

\section{5. 'Causal Stories', 'Orders of Worth' and 'Ecologising'}

The metaphor of an arena also alludes to the 'public policy arena' and arguably then more obviously to politics and (potential) acts of transformation, moving beyond a "cacophony of voices" (Castree, 2013). The accounts produced are no longer unbiased neutral accounts of the 'truth' from organisational actors, but challenges to such a notion. They provide partisan attempts at persuasion (Spence, 2009), or at the very least an outspoken bearing witness to something considered an anathema to one's beliefs and values as in the earlier case of the cairn and Turner's speech or perhaps a final act of defiance of 'speaking truth to power' (Gray et al., 2014; Tregidga, 2017). Vinnari and Dillard (2016, p.25) building on the pluralist agenda of Brown (2009) and Brown et al. (2015) refer to the "moment of decision" and ask how can "...democratic discussion and debate... maintain its pluralistic ethos while being focused in such a way as to ultimately lead to choosing and implementing an action." While Laclau and Mouffe (1985) and Latour (2004) loom large in their analysis, we suggest additional perspectives from political science and the pragmatic sociology of Boltanski and Thévenot can help further elucidate a broadening out and opening up of accounts of human-nature relations. 
First, we highlight the work of Deborah Stone (1989). She suggests that one way in which 'difficult situations' can be turned into problems that come to be seen as having human causes and thus become amenable to human (policy) actions is through 'causal stories'. As she notes, while political identity, articulation of the details of the difficulties, and language and symbols (discourse) all make up components of political action, what ties them together as a potentially effective means for transformation is a causal thread. Political actors do not simply accept and promote the causal models of science, she notes. Within bounds, they construct (frame) their own. And, in doing so, in order to escalate their appeal within the polity, they articulate both an empirical (identify causal mechanisms) and a moral (apportion blame and responsibility) case.

Stone (1989) illustrates how causal stories manufactured by political actors blend facts and values to construct cases of 'causation'. When these cases are constructed as intentional, inadvertent or mechanical and distinguished from 'accidental' or natural causes (acts of God - cases of unintended consequences from unguided events), they potentially become a means for policy reform. She illustrates, for example, the success of consumer and environmental activists like Ralph Nader in generating law change by producing accounts that tied known and purposeful action with intended or unintended consequences. Of course, other (political) actors will work hard to resist such accounts, working instead to cast considerable doubt and uncertainty on the processes of causation, or seeking to frame events as neutral, natural or accidental. Accounts of the causes, consequences and effects of human actions are not there to be discovered but are actively constructed and contested. We might ask, then, what are the empirical and (a)moral causal threads that pervade particular and situationally determined accounts of human-nature relations? How are they pieced together? By whom and with what motivations? And with what effects?[22]

The blending of facts and values also emerges in Latour's $(1998,2004)$ work on politics and ecology, as does discussion of framing, means-ends relationships, and finding or failing to find common appeal. Vinnari and Dillard (2016) draw on Latour's (2004) Politics of Nature and focus on four key frames or functions that underpin contested accounts: the scientific, the political, the economic and the moral. Some of Latour's ideas on 'nature', however, can be traced to his earlier work (Latour, 1998), where he draws extensively on Boltanski and Thévenot's (1991/2006) 'orders of worth' framework.

Table 1 provides an overview of seven orders of worth, and while there is not the space here to elaborate these in detail (see Boltanski and Thévenot, 1991/2006; Thévenot et al., 2000; Blok, 2013; and in accounting, Annisette and Richardson, 2011; Annisette et al., 2017), a few observations are important. First, these orders of worth are modes or regimes of justification used in argumentation. They might be called frames or logics brought to bear in disputes and, as Thévenot et al. (2000, pp. 236-239) argue, they go beyond individual viewpoints to 
attempts to generalise or universalise statements or claims in an appeal to the common good[23]. Second, in the original development there were only six orders of worth - the 'green' order of worth was subsequently developed, and remains plural itself according to Blok (2013)[24]. Third, they can be used to form positive justifications or they can be used to denounce statements or claims framed within other orders of worth. Fourth, they are more than frames for narrative rhetorical accounts, the regimes are situationally grounded with other elements and protagonists seek to provide 'proof' for their assertions to claim legitimacy.

[Table 1 about here]

Each of the orders of worth has the capacity to be used to justify particular decisions and actions that include 'nature'. As we noted earlier in the paper, nature can be represented and conveyed as monetised value and justified within a market logic of prices and commodified goods. Equally, such a framing and justification can be opposed from the perspective of inspired experiences and sublime grace perhaps as illustrated in the nature writing of Potton, Muir and others. The cairn and Turner's speech draw clear associations with the equal rights of citizens and the collective good arguably indicating a civic justification. In other instances, nature is articulated as a natural 'resource' to be efficiently and rationally exploited as part of an industrial regime. It should be clear that to the extent that accounting and management systems conventionally capture and express justifications for the environment, they seem firmly embedded within the market and industrial logics of (at best) eco-efficiency, win-win, tradable permits, green products, green labelling, eco-audits, etc. In examining the justifications for meat eating and the industrial production of pork, for example, Thorslund and Lassen $(2016$, see also Sayers, 2016) remind us that while a plurality of moral orders of worth are used to justify such practices, the justifications often occur in distinct, specific, separate contexts, thus permitting individuals to draw from different and conflicting orders of worth in a form of cognitive dissonance. We may express ourselves as customers, citizens, and/or animal rights activists depending on the situational context of the farm-to-plate chain.

Building on earlier work, Thévenot et al. (2000, p. 256-257) articulate the 'green regime' as extending political and moral concern beyond common humanity to communities of future generations and to non-human entities. Much as ecocentrism and deep ecology articulate a non-human ethical philosophy respecting an intrinsic value of nature, non-human entities, then, become invested as moral ends, and potentially as legal as well as accounting entities[25]. For his part in articulating a 'seventh' regime, Latour (1998, pp. 230-231) rejects 
such a position, arguing instead for an understanding of human-nature relationships as complex and uncertain.

What in fact is 'common' humanity? Boltanski and Thévenot were content with the usual reading offered by the canonical commentators of political philosophy they chose to consider. They took for granted the detached human offered to them by the humanist tradition, the human whose ultimate risk would be to be confused with a-human nature. But non-human is not inhuman. If ecology has nature as its goal and not humans, it follows that there can be no regime of ecology. But if the aim of ecology is to open up the question of humanity, it conversely follows that there is a 'seventh regime.' The meaning of the adjective 'common' in the expression 'common humanity' changes totally if the non-humans are not 'nature.'

The question opened up by the 'seventh regime' is to know what would a human be without elephants, plants, lions, cereals, oceans, ozone or plankton?...The regime of ecology does not at all say that we should shift our allegiance from the human realm to nature...The regime of ecology simply says that we do not know what makes the common humanity of human beings... Why don't we know? Because of the uncertainty concerning the relationship between means and ends.

Drawing on and adapting Kant (1956, p. 90), Latour (1998, p. 231-232) articulates the view that:

\begin{abstract}
...rivers, animals, biotopes, forests, parks and insects.... should, as for humans, never [be considered] as simply means but always also as ends. What doesn't hold together in Kant's definition is the truly incredible idea that simple means could exist and that the principle of autonomy and freedom would be reserved for man in isolation, i.e. for the inhuman. On the other hand, what doesn't hold together in ecology's theories is the improbable belief in the existence of a nature external to humans and threatened by the latter's domination and lack of respect.
\end{abstract}

It is this conjunction of actors who can never take each other as simple means which explains the uncertainty into which we are plunged by the 'seventh regime.' No entity is merely a means. There are always also ends. In other words, there are only mediators.

As Latour (1998, p. 233, fn. 29) notes (our emphasis), "there is no anthropomorphism in the reference to the river taking its revenge, merely the sometimes painful revelation of a being in its own right with its own freedom and its own ends." Ecologising, for Latour (1998) then, is recognising that we do not know for sure what is interconnected and woven together. He rejects anthropocentrism, and distances himself from deep ecology, ecocentrism and the intrinsic value of nature; instead articulating "a decentred uncertainty... [a] more-than-human ethics of volatile ecological attachment..." (Blok, 2013, p. 6). We are "feeling our way, experimenting, trying things out. [It means recognising] there are... no more things... [we need] procedures that make it possible to follow a network of quasi-objects whose relations of subordination remain uncertain and which thus require a new form of political activity" (Latour, 1998, pp. 232-233). The difficulty we have, however, according to Blok (2013, p. 7) is that in producing such a radical departure from Boltanski and Thévenot's framework, we are left with no pragmatic tools (available grammars of justification and critique) by which to analyse actors' political and moral commitments to ecology. Latour's ecologising provides a theoretically interesting treatise, but it achieves little in identifying the substantive cognitivemoral attachments of political ecology, which remain to be worked out (Blok, 2013). Nonetheless, what this discussion does usefully articulate is the level of moral and political 
complexity of human-non-human relations, and just how thoroughly impoverished (theoretically and practically) environmental accounts remain.

This special issue features various tentative attempts to move beyond such an impoverished state - most obviously Cuckston (2017) and Feger and Mermet (2017). For example, Cuckston's (2017, p. xxx) theorisation of how "accounting can organise non-human life within socio-ecological systems" provides insights into the ways in which scientific site classifications and associated forms of ecological monitoring, create new visibilities to enable forms of human action and intervention that are better aligned with ecological conservation and restoration. From a socionature perspective (Castree and Braun 2001), Cuckston (2017, pp. $x x x$ ) highlights that humans "act to produce a world in which non-human life can thrive". The justification for the deployment of new calculative practice within forms of ecological intervention depends upon the specific interests and motives of those involved:

[While ecology-centred accounting] can be used to further the economic interests of one or more humans, [...] if - as in the case analysed here - ecology-centred accounting is designed and deployed by people whose interests lie in conserving biodiversity... then this power can also be used to [...] aid biodiversity conservation"

Interestingly, while the efforts of those involved in the restoration of the blanket bog are clearly well-motivated, even this form of intervention has been the subject of some controversy. The UK-based columnist and commentator George Monbiot, for example, has expressed concern about the merits of interventions intended to restore nature to some predefined state. In his recent book Feral, Monbiot (2013) argues that humans should not attempt to recreate an ecosystem of the past. Instead, nature should be left to find its own way.

Such arguments suggest that, even where new forms of ecological accounts may well offer the potential to improve the management of biodiversity and sustainability within socioecological systems, any single account or single producer of an account will not reflect the diversity of views and perspectives involved. Even if, as Cuckston (2017) argues, we are all very much inside the accounting entity, we may have very different views not only on what should happen, but also on how the entity should be accounted for. For those wishing to contribute to addressing ecological challenges, for example by following Feger and Mermet's (2017) research agenda, this helpfully reminds us to question the underlying politics and ethics of accounts that are intertwined in environmental management and to consider whose nature is to be managed or saved (Carolan, 2006). 


\title{
6. Going Forward
}

So also with cows. The cowman who clears his range of wolves does not realize that he is taking over the wolf's job of trimming the herd to fit the range. He has not learned to think like a mountain. Hence we have dustbowls, and rivers washing the future into the sea [26].

(Leopold, 1949, p. 140)

\begin{abstract}
Ecosystems have their own integrity, their will to flourish. Living things other than humans have their own reason, their own sentience, their own will to flourish. Our challenge in engaging in new ways of thinking and doing connectivity is to embed the human in the non-human, and to enlarge human conversations so that we may find ways to engage with, learn from and communicate our embeddedness in the world's own expressivity and will to flourish
\end{abstract}

(Rose and Robin, 2004)

This paper has traced efforts to broaden the parameters of what constitutes (environmental) accounting. Despite work to conceptualise counter accounts, contested arenas or orientate analytical gaze towards other entities, environmental accounting research remains firmly anchored in the model of accounting as information production and dissemination by economic entities. This approach and focus is unlikely to fulfil the aspirations of those within the accounting academy to contribute towards ecological sustainability and social justice. How then might future research develop? Provoked by Latour's encouragement to 'feel', 'follow' and 'experiment' in the process of ecologising; Orbuch's call to conceptualise accounts as objects, means and products of enquiry; and wishing to explore the possibilities of Boltanski and Thévenot's 'orders of worth' framing, we have identified four areas for further research.

First, future research could critically examine historical and contemporary case studies of calculative practices that mediate human-nature relations. As accounting and associated technologies such as impact bonds become embedded in environmental governance, critical examinations of how they work (or not) are needed. Longitudinal case studies would be particularly valuable in allowing researchers to trace the impact of such initiatives and the extent to which they succeed in their original aspirations to address ecological challenges. It is possible that such analyses can aid scholars to generate alternatives in conjunction with other disciplines and take account of the organisations, institutional and political accountabilities at play when attending to socio-ecological challenges (Feger and Mermet, 2017; Sullivan and Hannis 2017).

Second, a focus on socio-ecological controversies and contested arenas may continue to offer valuable opportunities to enhance conceptualisation of accounts and accountability that disrupt the dominant information model so characteristic of past research. This will push the parameters of what constitutes a legitimate environmental account. Future research could examine different forms of accounts (e.g. Scott and Lyman, 1968; Orbuch, 1997), recognising the different orders of worth that may be conveyed (Boltanski and Thévenot, 2006; Blok, 2013), and understanding how they are constructed as causal stories (Stone, 1989) or used as effective strategies (Moody and Thévenot, 2000) in environmental disputes but also where 
both singular and more complex non-human entities (e.g. animals, rivers, forests, lakes) feature at the centre of the justification and articulatory practices. When doing so, researchers need to justify their own choices regarding the accounts that they deem as legitimate objects of enquiry. Work on pluralist accounts and radical democracies would likely enhance future studies in this area (Brown et al., 2015) alongside that which has examined and experimented with the use of visual methods to support participation in decision-making and articulation of different ways of knowing human-nature relations (e.g. Bastian et al., 2017; Fantini, 2017).

Third, future research could examine narratives expressed through photographs, sculpture or fiction in collaboration with others from environmental humanities recognising the messy, contingent and complex qualities of social-ecological change (Loftus, 2016). This may mean getting outside and developing ecological sensitivity (Whiteman, 2010) and joining artscience collaborations to understand different ways of knowing (Bastian, et al., 2017). It also requires understanding the centrality of human representation of nature through language and other media (e.g. Cox, 2012; Macfarlane, 2015). And, it might also require researchers to follow Hines' (1988) apprentice and master metaphor, ask other experts, and walk in the apprentice's footsteps and learn alongside researchers from other disciplines and those outside the academy (Waterton, 2003).

Fourth, for those researchers interested in engagement with stakeholders, interdisciplinary efforts may well lead to experimentation in the design and creation of different accounts and accountability practices, recognising the contribution of different epistemic communities (Castree, 2013; Whatmore and Landström, 2011). When participating in such work, we remind researchers to ask "accounts of what?" And "accountability to and for whom?" Remembering that non-human entities co-exist, and remembering the warnings from Cooper (1992) and Hines (1991) that accounting attempts to fix what is dynamic and can be transformed through accounting practice. Collaborations with scientists, arts and humanities scholars could offer ways to conceptualise accounts, accounting and accountabilities enriching understanding of accounting in relation to organisations, markets, and socio-ecological change (Chua, 2011; Gendron, 2015; Miller \& Power 2013; Parker, 2011). Moreover, by experimenting and exploring other fields, such as nature writing, social campaigns, or ecology, accounting may continue to contribute to more ecologically sustainable and socially just futures.

In finishing up his tour of the ways in which nature has been subject to the human imagination, from the sciences to the arts and humanities and within the social sciences, Simmons (2013) resists the idea that there is only one road - that of scientific realism. In fact, for Simmons, very much like Latour, there is only the road - our models and constructions are too imperfect and provisional, and on this journey we need to remain open to all possibilities within an ontological democracy. Drawing on a Tibetan metaphor, Simmons (2013, p. 160) 
suggests that we need to free our minds of the dominant conceptions and cultural constraints by which we box in nature. "...watching the prayer flags blowing in the wind. The novice asked the master 'does the flag move or does the wind move?' There was a long silence before the master replied, 'it is the mind that moves'."

He suggests that it is the arts that serve to presage movements and transformations in society and it is they that have the potential to shift environmental cognitions. Our plea, then, is to break open the very much limited notion of 'environmental' accounting in which our scholarship has become so ensnared. We seek to promote and generate a wider, wilder, more vivid interdisciplinary mosaic that is fully representative of the political and moral concerns at play in 'accounts' of 'nature' and which may also prove more enchanting to our scholarship, to our lives, and to the lives and relations we have with the non-human entities that make up our planet.

\section{References}

Abram, D. (1997), The Spell of the Sensuous: Perception and Language in a More-than-Human World, Pantheon Books, New York.

Adams, C.A. (2004), "The ethical, social and environmental reporting-performance portrayal gap", Accounting, Auditing \& Accountability Journal, Vol. 17 No. 5, pp. 731-757.

Adams, C. A. and Larrinaga-González, C. (2007), "Engaging with organisations in pursuit of improved sustainability accounting and performance", Accounting, Auditing \& Accountability Journal, Vol. 20 No. 3, pp. 333-355.

Alvesson, M., \& Sandberg, J. (2014), "Habitat and habitus: Boxed-in versus box-breaking research", Organization Studies, Vol. 35 No. 7, pp. 967-987.

Annisette, M., and Richardson, A. J. (2011), "Justification and accounting: applying sociology of worth to accounting research", Accounting, Auditing \& Accountability Journal, Vol. 24 No. 2, pp. 229249.

Annisette, M., Vesty, G. and Amslem, T. (2017), "Accounting Values, Controversies, and Compromises in Tests of Worth", in Cloutier, C., Gond, J-P. and Leca, B. (eds.) Justification, Evaluation and Critique in the Study of Organizations (Research in the Sociology of Organizations, Volume 52), Emerald Publishing Limited, pp.209-239.

Arendt, H. (1958), The Human Condition, University of Chicago Press, Chicago.

Armstrong, P. (2017), "Peter Armstrong owns up", Critical Perspectives on Accounting, Vol. 45, pp. 111.

Atkins, J. and Thomson, I. (2014), "Accounting for nature in 19th century Britain: William Morris and the defence of the fairness of the earth", in Jones, M. (Ed.), Accounting for Biodiversity, Routledge, London.

Atkins, J., and Maroun, W. (forthcoming), "Accounting for Extinction", Accounting, Auditing \& Accountability Journal.

Balboa, C.M. (2016), "Accountability of Environmental Impact Bonds: The Future of Global Environmental Governance?", Global Environmental Politics, Vol. 16 No. 2, pp. 33-41.

Bansal, P., and Roth, K. (2000), "Why companies go green: A model of ecological responsiveness", Academy of management journal, Vol. 43 No. 4, pp. 717-736.

Barry, A. (2013), Material Politics: Disputes Along the Pipeline, Wiley-Blackwell, Oxford.

Bastian, M., Jones, O., and Moore, E. (eds.) (2016), Participatory Research in More-than-human Worlds, Routledge, London.

Bayon, R., and Jenkins, M. (2010), "The business of biodiversity", Nature, Vol. 466 No. 7303, pp. 184185. 
Bebbington, J., and Gray, R. (1993), "Corporate accountability and the physical environment: social responsibility and accounting beyond profit", Business Strategy and the Environment, Vol. 2 No. 2, pp. 1-11.

Bebbington, J. and Thomson, I. (2013), "Sustainable development, management and accounting: Boundary crossing", Management Accounting Research, Vol. 24 No. 4, pp. 277-283.

Bebbington, J. and Larrinaga, C. (2014), "Accounting and sustainable development: An exploration", Accounting, Organizations and Society, Vol. 39 No. 6, pp. 395-413.

Bebbington, J., Kirk, E.A. and Larrinaga, C. (2012), "The production of normativity: A comparison of reporting regimes in Spain and the UK", Accounting, Organizations and Society, Vol. 37 No. 2, pp. 78-94.

Bebbington, J., Unerman, J., and O'Dwyer, B. (Eds.) (2014), Sustainability accounting and accountability, Routledge, London.

Bebbington, J., Gray, R., Hibbitt, C., and Kirk, E. (2001), Full cost accounting: An agenda for action. ACCA research report. ACCA, London.

Beder, S., (2002), Global spin: The corporate assault on environmentalism, Green Books, Totnes, Devon.

Birkin, F. (1996), "The ecological accountant: from the cogito to thinking like a mountain", Critical Perspectives on Accounting, Vol. 7 No. 3, pp. 231-257.

Birkin, F. (2003), "Ecological accounting: new tools for a sustainable culture", International Journal of Sustainable Development \& World Ecology, Vol. 10 No. 1, pp. 49-61.

Birkin, F., Edwards, P. and Woodward, D. (2005), "Accounting's contribution to a conscious cultural evolution: an end to sustainable development", Critical Perspectives on Accounting, Vol. 16 No. 3, pp. 185-208.

Bland, W. L., and Bell, M. M. (2007), "A holon approach to agroecology", International Journal of agricultural sustainability, Vol. 5 No. 4, pp. 280-294.

Blok, A. (2013), "Pragmatic sociology as political ecology: On the many worths of nature (s)", European Journal of Social Theory, Vol. 16 No. 4, pp. 492-510.

Boiral, O. (2016), "Accounting for the unaccountable: Biodiversity reporting and impression management", Journal of Business Ethics, Vol. 135 No. 4, pp. 751-768.

Boltanski, L., and Thévenot, L. (2006), On Justification: Economies of Worth. Princeton University Press. (First published in French in 1991 as De la justification les économies de la grandeur).

Brockington, D., and Duffy, R. (2010), "Capitalism and conservation: the production and reproduction of biodiversity conservation", Antipode, Vol. 42 No. 3, pp. 469-484.

Brockington, D., and Duffy, R. (Eds.). (2011), Capitalism and Conservation, John Wiley \& Sons, London.

Brown, J. (2009), "Democracy, sustainability and dialogic accounting technologies: Taking pluralism seriously", Critical Perspectives on Accounting, Vol. 20 No. 3, pp. 313-342.

Brown, J., Dillard, J. and Hopper, T. (2015), "Accounting, accountants and accountability regimes in pluralistic societies", Accounting, Auditing \& Accountability Journal, Vol. 28 No. 5, pp. 626650.

Buchanan, K. S. (2013), "Contested discourses, knowledge, and socio-environmental conflict in Ecuador", Environmental science \& policy, Vol. 30, pp. 19-25.

Bull, J. W., Suttle, K. B., Gordon, A., Singh, N. J., and Milner-Gulland, E. J. (2013), "Biodiversity offsets in theory and practice", Oryx, Vol. 47 No. 3, pp. 369-380.

Burritt, R. L., and Schaltegger, S. (2010), "Sustainability accounting and reporting: fad or trend?", Accounting, Auditing \& Accountability Journal, Vol. 23 No. 7, pp. 829-846.

Büscher, B., Dressler, W., and Fletcher, R. (2014), Nature ${ }^{T M}$ Inc. Environmental Conservation in the Neoliberal Age, The University of Arizona Press, Tuscon.

Business and Biodiversity Offsets Programme (BBOP). (2012), Standard on Biodiversity Offsets. BBOP, Washington, DC. http://www.forest-trends.org/documents/files/doc 3078.pdf accessed 7 July 2017.

Callicott, J. B. (1984), "Non-anthropocentric value theory and environmental ethics", American Philosophical Quarterly, Vol. 21 No. 4, pp. 299-309.

Callicott, J. B. (1989), In defense of the land ethic: Essays in environmental philosophy, Suny Press, Albany, NY. 
Carolan, M.S. (2006), "Conserving Nature, but to What end?: Conservation Policies and the Unanticipated Ecologies They Support", Organization \& Environment, Vol. 19 No. 2, pp. 153170.

Castree, N., (2005), Nature: the adventures of a concept, Routledge, London.

Castree, N. (2008a), "Neoliberalising nature: the logics of deregulation and reregulation", Environment and Planning A, Vol. 40 No. 1, pp. 131-152.

Castree, N. (2008b), "Neoliberalising nature: processes, effects, and evaluations", Environment and Planning A, Vol. 40 No. 1, pp. 153-173.

Castree, N. (2013), Making sense of nature, Routledge, London.

Castree, N., and Braun, B. (eds.) (2001), Social nature: theory, practice and politics, Blackwell, Oxford and Malden.

Christian Aid. (2004), Behind the mask: The real face of corporate social responsibility. Christian Aid, London.

Chua, W.F. (2011), "In Search of "Successful" Accounting Research", European Accounting Review, Vol. 20 No. 1, pp. 27-39.

CIMA. (2014), Accounting for Natural Capital: the Elephant in the Boardroom, http://www.cimaglobal.com/Documents/Thought leadership docs/Sustainability\%20and\% 20Climate\%20Change/CIMA-accounting-for-natural-capital.pdf accessed 13 June 2017.

Clark, C. and Nicola, D. (2013), "Bringing Social Impact Bonds to the Environment", Stanford Social Innovation Review, accessed 30 June 2017

https://ssir.org/articles/entry/bringing social impact bonds to the environment

Climate Bonds Initiative. (2016), "Explaining green bonds", https://www.climatebonds.net/market/explaining-green-bonds (accessed 31 January 2017).

Connolly, L., and Cullen, J. (2017), "Animals and Organisations: An Ethic of Care Framework", Organization \& Environment, in press.

Cooper, C. (1992), "The non and nom of accounting for $(\mathrm{m})$ other nature", Accounting, Auditing \& Accountability Journal, Vol. 5 No. 3, pp. 16-39.

Cooper, C., and Senkl, D. (2016), "An (other) truth: a feminist perspective on KPMG's true value", Sustainability Accounting, Management and Policy Journal, Vol. 7 No. 4, pp. 494-516.

Cooper, S. M., and Owen, D. L. (2007), "Corporate social reporting and stakeholder accountability: The missing link", Accounting, Organizations and Society, Vol. 32 No. 7, pp. 649-667.

Cox, R. (2012), Environmental communication and the public sphere, Sage publications, London.

Cronon, W. (ed.) (1995), Uncommon Ground: Rethinking the Human Place in Nature, W. W. Norton \& Co., New York, pp. 69-90.

Cuckston, T. (2017), "Ecology-centred accounting for biodiversity in the production of a blanket bog", Accounting, Auditing \& Accountability Journal, this issue.

Darnall, N., Henriques, I., and Sadorsky, P. (2010), "Adopting proactive environmental strategy: The influence of stakeholders and firm size", Journal of Management Studies, Vol. 47 No. 6, pp. 1072-1094.

Dearing, J.A., Wang, R., Zhang, K., Dyke, J.G., Haberl, H., Hossain, M.S., Langdon, P.G., Lenton, T.M., Raworth, K., Brown, S., Carstensen, J., Cole, M.J., Cornell, S.E., Dawson, T.P., Doncaster, C.P., Eigenbrod, F., Flörke, M., Jeffers, E., Mackay, A.W., Nykvist, B. and Poppy, G.M. (2014), "Safe and just operating spaces for regional social-ecological systems", Global Environmental Change, Vol. 28, pp. 227-238.

Deegan, C. (2017), "Twenty five years of social and environmental accounting research within Critical Perspectives of Accounting: Hits, misses and ways forward", Critical Perspectives on Accounting, Vol. 43, pp. 65-87.

Deegan, C., and Blomquist, C. (2006), "Stakeholder influence on corporate reporting: An exploration of the interaction between WWF-Australia and the Australian minerals industry", Accounting, Organizations and Society, Vol. 31 No. 4, pp. 343-372.

Delmas, M. A., and Toffel, M. W. (2008), "Organizational responses to environmental demands: Opening the black box", Strategic Management Journal, Vol. 29 No. 10, pp. 1027-1055.

Dey, C. (2003), "Corporate 'silent' and 'shadow' social accounting", Social and Environmental Accountability Journal, Vol. 23 No. 2, pp. 6-9. 
Dey, C., and Gibbon, J. (2014), "External accounts", In Sustainability Accounting and Accountability, Bebbington, J., Unerman, J. and O'Dwyer, B. (Eds.), Routledge, London, pp. 108-123.

Dey, C., and Russell, S. (2014), "Who speaks for the river?" In Accounting for Biodiversity, Jones, M. (Ed.), Routledge, London, pp. 245-265.

Dey, C., Russell, S. and Thomson, I. (2011), "Exploring the potential of shadow accounts in problematizing institutional conduct", in Ball, A. and Osbourne, S. (Eds.), Social Accounting and Public Management: Accountability for the Common Good, Routledge, London, pp. 6475.

Dierkes, M., and Antal, A. B. (1985), "The usefulness and use of social reporting information", Accounting, Organizations and Society, Vol. 10 No. 1, pp. 29-34.

Dierkes, M., and Antal, A. B. (1986), "Whither corporate social reporting: Is it time to legislate?", California Management Review, Vol. 28 No. 3, pp. 106-121.

Dierkes, M., and Preston, L. E. (1977), "Corporate social accounting reporting for the physical environment: A critical review and implementation proposal", Accounting, Organizations and Society, Vol. 2 Vo. 1, pp. 3-22.

Dryzek, J. (1997), The Politics of the Earth, Oxford University Press, Oxford.

Eckersley, R. (1992), Environmentalism and Political Theory: Toward an Ecocentric Approach, Suny Press, Albany, NY.

Eftec. (2017), http://www.eftec.co.uk/ accessed 13 June 2017.

Egan, M. (2014), "Making water count: water accountability change within an Australian university", Accounting, Auditing \& Accountability Journal, Vol. 27 No. 2, pp. 259-282.

Estes, R. W. (1972), "Socio-economic accounting and external diseconomies", The Accounting Review, Vol. 47 No. 2, pp. 284-290.

Etzion, D., and Ferraro, F. (2010), "The role of analogy in the institutionalization of sustainability reporting", Organization Science, Vol. 21 No. 5, pp. 1092-1107.

Everett, J. (2004), "Exploring (false) dualisms for environmental accounting praxis", Critical Perspectives on Accounting, Vol. 15 No. 8, pp. 1061-1084.

Fantini, E. (2017), "Picturing waters: a review of Photovoice and similar participatory visual research on water governance", Wiley Interdisciplinary Reviews: Water, Vol. 8, pp. 1226-16.

Fazey, I., Moug, P., Allen, S., Beckmann, K., Blackwood, D., Bonaventura, M., Burnett, K., Danson, M., Falconer, R., Gagnon, A.S., Harkness, R., Hodgson, A., Holm, L., Irvine, K.N., Low, R., Lyon, C., Moss, A., Moran, C., Naylor, L., O'Brien, K., Russell, S., Skerratt, S., Rao-Williams, J. and Wolstenholme, R. (2017), "Transformation in a changing climate: a research agenda", Climate and Development, online, pp. 1-21.

Feger, C. and Mermet, L. (2017), "A Blueprint towards Accounting for the Management of Ecosystems", Accounting, Auditing \& Accountability Journal, this issue.

Ferreira, C. (2017), "The contested instruments of a new governance regime: accounting for nature and building markets for biodiversity offsets", Accounting, Auditing \& Accountability Journal, this issue.

Fourcade, M. (2011), "Cents and sensibility: Economic valuation and the nature of "nature"", American Journal of Sociology, Vol. 116 No. 6, pp. 1721-1777.

Gaia, S., and Jones, M.J. (2017), "UK local councils reporting of biodiversity values: a stakeholder perspective", Accounting, Auditing \& Accountability Journal, this issue.

Gallhofer, S., Haslam, J., Monk, E. and Roberts, C. (2006), "The emancipatory potential of online reporting: the case of counter accounting", Accounting, Auditing \& Accountability Journal, Vol. 19 No. 5, pp. 681-718.

Gambling, T. (1974), Societal Accounting, Allen and Unwin, London.

Gendron, Y. (2015), "Accounting academia and the threat of the paying-off mentality", Critical Perspectives on Accounting, Vol. 26, pp. 168-176.

Georgakopoulos, G., and Thomson, I. (2008), "Social reporting, engagements, controversies and conflict in an arena context", Accounting, Auditing \& Accountability Journal, Vol. 21 No. 8, pp. 1116-1143.

Gibbs, L.M. (2009), "Water places: cultural, social and more-than-human geographies of nature', Scottish Geographical Journal, Vol. 125 No. 3/4, pp. 361-369. 
Ginn, F., and Demeritt, D. (2009), "Nature", In Key concepts in Geography, (2 edn.), Sage, London, pp. 300-311.

Global Reporting Initiative (GRI). (2014), GRI G4 - Part 1 - Reporting Principles and Standard Disclosures, https://www.globalreporting.org/resourcelibrary/GRIG4-Part1-ReportingPrinciples-and-Standard-Disclosures.pdf accessed 30 June 2017.

Gough, S., Scott, W., and Stables, A. (2000), "Beyond O'Riordan: balancing anthropocentrism and ecocentrism", International Research in Geographical and Environmental Education, Vol 9 No. 1, pp. 36-47.

Gray, R. (1992), "Accounting and environmentalism: an exploration of the challenge of gently accounting for accountability, transparency and sustainability", Accounting, Organizations and Society, Vol. 17 No. 5, pp. 399-425.

Gray, R. (2000), "Current developments and trends in social and environmental auditing, reporting and attestation: A review and comment", International Journal of Auditing, Vol. 4 No. 3, pp. 247-268.

Gray, R. (2002a), "The social accounting project and accounting organizations and society: privileging engagement, imaginings, new accountings and pragmatism over critique?", Accounting, Organizations and Society, Vol. 27 No. 7, pp. 687-708.

Gray, R. (2002b), "Of messiness, systems and sustainability: towards a more social and environmental finance and accounting", The British Accounting Review, Vol. 34 No. 4, pp. 357-386.

Gray, R. (2010a), "A re-evaluation of social, environmental and sustainability accounting: an exploration of an emerging trans-disciplinary field?", Sustainability Accounting, Management and Policy Journal, Vol. 1 No. 1, pp. 11-32.

Gray, R. (2010b), "Is accounting for sustainability actually accounting for sustainability... and how would we know? An exploration of narratives of organisations and the planet", Accounting, Organizations and Society, Vol. 35 No. 1, pp. 47-62.

Gray, R., and Laughlin, R. (1991), "Editorial: the coming of the green and the challenge of environmentalism", Accounting, Auditing \& Accountability Journal, Vol. 4 No. 3, pp. 5-8.

Gray, R., and Guthrie, J. (Eds.) (2007), Social accounting, mega accounting and beyond: A festschrift in honour of MR Mathews, Centre for Social and Environmental Accounting Research (CSEAR), University of St. Andrews: St. Andrews.

Gray, R., and Laughlin, R. (2012), "It was 20 years ago today: Sgt Pepper, accounting, auditing \& accountability journal, green accounting and the blue meanies", Accounting, Auditing \& Accountability Journal, Vol. 25 No. 2, pp. 228-255.

Gray, R., Owen, D., and Maunders, K. (1987), Corporate social reporting: Accounting and accountability, Prentice-Hall International.

Gray, R., Dillard, J., and Spence, C. (2009), "Social accounting research as if the world matters: an essay in Postalgia and a new absurdism", Public Management Review, Vol. 11 No. 5, pp. 545-573.

Gray, R., Adams, C., and Owen, D. (2014), Accountability, social responsibility and sustainability: Accounting for society and the environment, Pearson Higher Ed, New York.

Gray, R., Brennan, A. and Malpas, J. (2014), "New accounts: Towards a reframing of social accounting", Accounting Forum, Vol. 38 No. 4, pp. 258-273.

Gray, R., Dey, C., Owen, D., Evans, R., and Zadek, S. (1997), "Struggling with the praxis of social accounting: Stakeholders, accountability, audits and procedures", Accounting, Auditing \& Accountability Journal, Vol. 10 No. 3, pp. 325-364.

Greenpeace New Zealand. (1996), Pulp fiction: the environmental impact of the Tasman Pulp and Paper mill on the Tarawera River, Greenpeace New Zealand, Auckland.

Habermas, J. (1984), The Theory of Communicative Action, Volume I, Beacon, Boston, MA.

Hackmann, H. and St. Clair, A.L. (2012), Transformative cornerstones of Social Science research for Global change. Report of the International Social Science Council, Paris.

Hahn, R., Reimsbach, D., and Schiemann, F. (2015), “Organizations, climate change, and transparency: Reviewing the literature on carbon disclosure", Organization \& Environment, Vol. 28 No. 1, pp. 80-102.

Hazelton, J. (2013), "Accounting as a human right: the case of water information", Accounting, Auditing \& Accountability Journal, Vol. 26 No. 2, pp. 267-311.

Helm, D. (2015), Natural Capital: Valuing the Planet. Yale University Press, New Haven. 
Herbohn, K. (2005), "A full cost environmental accounting experiment", Accounting, Organizations and Society, Vol. 30 No. 6, pp. 519-536.

Heynen, N., and Robbins, P. (2005), "The neoliberalization of nature: Governance, privatization, enclosure and valuation", Capitalism Nature Socialism, Vol. 16 No. 1, pp. 5-8.

Hines, R. D. (1988), "Financial accounting: in communicating reality, we construct reality", Accounting, Organizations and Society, Vol. 13 No. 3, pp. 251-261.

Hines, R. D. (1991), "On valuing nature”, Accounting, Auditing \& Accountability Journal, Vol. 4 No. 3, pp. 27-29.

Hopwood, A. G. (2009), "Accounting and the environment", Accounting, Organizations and Society, Vol. 34 No. 3, pp. 433-439.

Howitt, R. and Suchet-Pearson, S. (2006), "Rethinking the building blocks: Ontological pluralism and the idea of "management", Geografiska Annaler: Series B, Human Geography, Vol. 88 No. 3, pp. 323-335.

Humphrey, C., O'Dwyer, B., and Unerman, J. (2017), "Re-theorizing the configuration of organizational fields: the IIRC and the pursuit of 'Enlightened' corporate reporting", Accounting and Business Research, Vol. 47 No. 1, pp. 30-63.

IIRC. (2013), The International <IR> Framework, https://integratedreporting.org/wpcontent/uploads/2013/12/13-12-08-THE-INTERNATIONAL-IR-FRAMEWORK-2-1.pdf accessed 16 June 2017.

Jamie, K. (2012), Sightlines: A Conversation with the Natural World, Sort of Books, London.

Jones, M. J., and Solomon, J. F. (2013), "Problematising accounting for biodiversity", Accounting, Auditing \& Accountability Journal, Vol. 26 No. 5, pp. 668-687.

Juniper, T. (2013), What has Nature Ever Done for Us?: How Money Really does Grow on Trees. Profile Books, London.

Kallis, G., Gómez-Baggethun, E., and Zografos, C. (2013), "To value or not to value? That is not the question", Ecological Economics, Vol. 94, pp. 97-105.

Kant, I. (1956), Critique of Practical Reason, Translated by Lewis White Beck, Liberal Arts Press, New York.

Katz, E., and Light, A. (Eds.). (2013), Environmental Pragmatism, Routledge, London.

Kolk, A., Levy, D., and Pinkse, J. (2008), "Corporate responses in an emerging climate regime: the institutionalization and commensuration of carbon disclosure", European Accounting Review, Vol. 17 No. 4, pp. 719-745.

KPMG. (2017), Introducing KPMG True Value, https://home.kpmg.com/content/dam/kpmg/ae/pdf/introduction-kpmg-truevalue.pdf accessed 25 June 2017.

KPMG/ACCA. (2015), Natural Capital and the Accountancy Profession, http://www.accaglobal.com/content/dam/ACCA Global/Technical/sus/NC and the Accou nting Profession.pdf accessed 15 June 2017.

Kuruppu, S., and Milne, M. J. (2010), "Dolphin deaths, organizational legitimacy and potential employees' reactions to assured environmental disclosures", Accounting Forum, Vol. 34 No. 1, pp. 1-19.

Laclau, E. (2005), On Populist Reason, Verso Books, Brooklyn, NY.

Laclau, E. and Mouffe, C. (2001/1985), Hegemony and Socialist Strategy: Towards a Radical Democratic Politics, Verso, London.

Laine, M. and Vinnari, E. (2017), "The transformative potential of counter accounts: a case of animal rights activism", Accounting, Auditing \& Accountability Journal, this issue.

Lanka, S., Khadaroo, I., and Böhm, S. (2017), "Agroecology accounting: biodiversity and sustainable livelihoods from the margins", Accounting, Auditing \& Accountability Journal, this issue.

Latour, B. (1998), "To modernise or ecologise? That is the question", in Braun, B. and Castree, N. (eds.) Remaking Reality: Nature at the Millennium, Routledge, London, pp. 221-242.

Latour, B. (2004), Politics of Nature. Harvard University Press, Cambridge, MA.

Lee, W. E., and Sweeney, J. T. (2015), "Use of discretionary environmental accounting narratives to influence stakeholders: the case of jurors' award assessments", Journal of Business Ethics, Vol. 129 No. 3, pp. 673-688. 
Lehman, G. (2017), "The language of environmental and social accounting research: The expression of beauty and truth", Critical Perspectives on Accounting, Vol. 44, pp. 30-41.

Lennox, J., Proctor, W. and Russell, S. (2011), "Structuring stakeholder participation in New Zealand's water resource governance", Ecological Economics, Vol. 70 No. 7, pp. 1381-1394.

Leopold, A. (1949), A Sand County Almanac, Oxford University Press, New York.

Lewis, M. W. (1994), Green delusions. Duke University Press, North Carolina.

Lilley, D. (2013), "Kathleen Jamie: Rethinking the externality and idealisation of nature", Green Letters. Vol. 17 No. 1, pp. 16-26.

Lister-Kaye, J. (2004), Song of the Rolling Earth, Abacus, London.

Lodhia, S., Jacobs, K., and Park, Y. J. (2012), "Driving public sector environmental reporting: the disclosure practices of Australian commonwealth departments", Public Management Review, Vol. 14 No. 5, pp. 631-647.

Loftus, A. (2016), "Questioning Socio-Ecological Transformations", Environmental Values, Vol. 25 No. 5, pp. 499-502.

Lubbers, E. (Ed.) (2002), Battling big business: Countering greenwash, infiltration, and other forms of corporate bullying, Green Books, Totnes, Devon.

Macdonald, H. (2014), $H$ is for Hawk, Random House, London.

MacDonald, K. I. and Corson, C. (2014), "Orchestrating Nature: Ethnographies of Nature ${ }^{\mathrm{TM}}$ Inc.", in B Büscher, W. Dressler and R. Fletcher, (eds.) Nature ${ }^{\mathrm{TM}}$ Inc.: New Frontiers of Environmental Conservation in the Neoliberal Age, Oxford University Press, London.

Macfarlane, R. (2015), Landmarks, Penguin. UK.

Maron, M., Hobbs, R. J., Moilanen, A., Matthews, J. W., Christie, K., Gardner, T. A. and McAlpine, C. A. (2012), "Faustian bargains? Restoration realities in the context of biodiversity offset policies", Biological Conservation, Vol. 155, pp. 141-148.

Mathews, M. R. (1984), "A suggested classification for social accounting research", Journal of Accounting and Public Policy, Vol. 3 No. 3, pp. 199-221.

Mathews, M. R. (1997), "Twenty-five years of social and environmental accounting research: is there a silver jubilee to celebrate?", Accounting, Auditing \& Accountability Journal, Vol. 10 No. 4, pp. 481-531.

Mattessich, R. (1964), Accounting and Analytical Methods: Measurement and Projection of Income and Wealth in the Micro-and Macro-Economy, Richard D. Irwin, Inc, Illinois.

Maunders K.T., and Burritt, R.L. (1991), "Accounting and ecological crisis", Accounting, Auditing \& Accountability Journal, Vol. 4 No. 3, pp. 9-26.

Medawar, C. (1976)," The social audit: a political view", Accounting, Organizations and Society, Vol. 1 No. 4, pp. 389-394.

Midgley, M. (1998), Animals and Why They Matter, University of Georgia Press, Georgia.

Miller, P. and Power, M. (2013), "Accounting, Organizing, and Economizing: Connecting Accounting Research and Organization Theory", The Academy of Management Annals, Vol. 7 No. 1, pp. 557-605.

Milne, M. J. (1991), "Accounting, environmental resource values, and non-market valuation techniques for environmental resources: A review", Accounting, Auditing \& Accountability Journal, Vol. 4 No. 3, pp. 81-109.

Milne, M. J. (1996b), “On sustainability; the environment and management accounting”, Management Accounting Research, Vol. 7 No. 1, pp. 135-161.

Milne, M.J. (1996a), "Capitalising and Appropriating Society's Rights to Clean Air: A Critical Commentary on The Problem with Reporting Pollution Allowances", Critical Perspectives on Accounting, Vol. 7 No. 6, pp. 681-695.

Milne, M. J. (2007), "Downsizing Reg (me and you)! Addressing the 'real' sustainability agenda at work and home", in Social Accounting, Mega Accounting and Beyond: A Festschrift in Honour of MR Mathews, Centre for Social and Environmental Accounting Research, St. Andrews, pp. 49-66.

Milne, M.J. (2013), "Phantasmagoria, Sustain-a-Babbling and the Communication of Corporate Social and Environmental Accountability", in The Routledge Companion to Accounting Communication, Jack, L., Craig, R. and Davison, J. (eds.), Routledge, London, pp. 135-153.

Milne, M. J., and Grubnic, S. (2011), "Climate change accounting research: keeping it interesting and different", Accounting, Auditing \& Accountability Journal, Vol. 24 No. 8, pp. 948-977. 
Milne, M. J., and Gray, R. (2013), "W(h)ither ecology? The triple bottom line, the global reporting initiative, and corporate sustainability reporting", Journal of Business Ethics, Vol. 118 No. 1 pp. 13-29.

Milne, M. J., Tregidga, H., and Walton, S. (2009), "Words not actions! The ideological role of sustainable development reporting", Accounting, Auditing \& Accountability Journal, Vol. 22 No. 8, pp. 1211-1257.

Monbiot, G. (2013), Feral: Searching for Enchantment on the Frontiers of Rewilding, Penguin, London. Moody, M., and Thévenot, L. (2000), "Comparing models of strategy, interests, and the public good in French and American environmental disputes", in Rethinking comparative cultural sociology: Repertoires of evaluation in France and the United States, Lamont, M. and Thévenot, L. (eds.), CUP, Cambridge, pp. 273-305.

Muir, J. (1869), Entry in Muir's Journal 27 July, 1869, in Limbaugh, R.H. and Kirsten E.L. (eds.) (1980) The John Muir Papers 1858-1957, University of the Pacific, Stockton, CA.

Muir, J. (1911), My First Summer in the Sierra, Houghton Mifflin Co, Boston \& New York.

Muir, J. (1915), Travels in Alaska, Houghton Mifflin Co, Boston \& New York.

Nash, R. F. (1989), The Rights of Nature: A History of Environmental Ethics, University of Wisconsin Press, Madison, WI.

Natural Capital Coalition. (2017), https://naturalcapitalcoalition.org/ accessed 13 June 2017.

Nelson, E. and Willey, E. (2001), "Issue frames that strike a value balance: A political psychology perspective", in S.D. Reese, O.H. Gandy Jr., A.E. Grant (Eds.), Framing public life, Lawrence Erlbaum Associates, Mahwah, NJ, pp. 245-266.

Norton, B. G. (1994), Toward Unity Among Environmentalists, Oxford University Press, Oxford.

Norton, B. G. (1999), "Pragmatism, adaptive management, and sustainability", Environmental Values, Vol. 8 No. 4, pp. 451-466.

O'Dwyer, B. (2011), "The case of sustainability assurance: Constructing a new assurance service", Contemporary Accounting Research, Vol. 28 No. 4, pp. 1230-1266.

O'Dwyer, B., and Owen, D. L. (2005). Assurance statement practice in environmental, social and sustainability reporting: a critical evaluation. The British Accounting Review, 37(2), 205-229.

O'Dwyer, B., Owen, D., and Unerman, J. (2011), "Seeking legitimacy for new assurance forms: The case of assurance on sustainability reporting", Accounting, Organizations and Society, Vol. 36 No. 1, pp. 31-52.

O'Neill, J. and Spash, C.L. (2000), Conceptions of Value in Environmental Decision-Making, Environmental Valuation in Europe, Policy Research Brief \#4, Cambridge Research for the Environment, Cambridge.

O'Neill, J., Holland, A., and Light, A. (2008), Environmental Values, Routledge, London.

Orbuch, T.L. (1997), "People's accounts count: The sociology of accounts", Annual Review of Sociology, Vol. 23 No. 1, pp. 455-478.

Owen, D. (2007), "Social and Environmental Accounting: Celebrating a silver jubilee of engagement and community", in Gray R.H. and J. Guthrie (eds.) Social Accounting, Mega Accounting and beyond: A Festschrift in Honour of M. R. Mathews, CSEAR Publishing, St. Andrews, pp. 67-76.

Owen, D. (2008), "Chronicles of wasted time?", Accounting, Auditing \& Accountability Journal, Vol. 21 No. 2, pp. 240-267.

Owen, D. L., Swift, T. A., Humphrey, C., and Bowerman, M. (2000), "The new social audits: accountability, managerial capture or the agenda of social champions?", European Accounting Review, Vol. 9 No. 1, pp. 81-98.

Parker, L. D. (2005), "Social and environmental accountability research: A view from the commentary box", Accounting, Auditing \& Accountability Journal, Vol. 18 No. 6, pp. 842-860.

Parker, L. D. (2011), "Twenty-one years of social and environmental accountability research: A coming of age", Accounting Forum, Vol. 35 No. 1, pp. 1-10.

Pascoe, J. (1957), Mr Explorer Douglas, (Revised Edition, Graham Langton, Canterbury University Press, Christchurch, New Zealand, 2000).

Perkiss, S., and Tweedie, D. (2017), "Social Accounting into Action: Religion as 'Moral Source'", Social and Environmental Accountability Journal, online, pp. 1-16.

Potton, C. (2016), So Far So Good, Potton \& Burton, Nelson, NZ. 
Power, M. (1997), "Expertise and the construction of relevance: accountants and environmental audit", Accounting, Organizations and Society, Vol. 22 No. 2, pp. 123-146.

Ramanathan, K. V. (1976), "Toward a theory of corporate social accounting", The Accounting Review, Vol. 51 No. 3, pp. 516-528.

Rankin, M., Windsor, C., and Wahyuni, D. (2011), "An investigation of voluntary corporate greenhouse gas emissions reporting in a market governance system: Australian evidence", Accounting, Auditing \& Accountability Journal, Vol. 24 No. 8, pp. 1037-1070.

Reber, B. H., and Berger, B. K. (2005), "Framing analysis of activist rhetoric: How the Sierra Club succeeds or fails at creating salient messages", Public Relations Review, Vol. 31 No. 2, pp. 185195.

Rimmel, G., and Jonäll, K. (2013), "Biodiversity reporting in Sweden: corporate disclosure and preparers' views", Accounting, Auditing \& Accountability Journal, Vol. 26 No. 5, pp. 746-778.

Rockström, J., Steffen, W., Noone, K., Persson, A., Chapin, F.S., III, Lambin, E., Lenton, T.M., Scheffer, M., Folke, C., Schellnhuber, H.J., Nykvist, B., de Wit, C.A., Hughes, T., van der Leeuw, S., Rodhe, H., Rodhe, Sorlin, S., Snyder, P.K., Costanza, R., Svedin, U., Falkenmark, M., Karlberg, L., Correll, R.W., Fabry, V.J., Hansen, J., Walker, B., Walker, B., Liverman, D., Richardson, K., Crutzen, P. and Foley, J. (2009), "Planetary boundaries: exploring the safe operating space for humanity", Ecology and Society, Vol. 14 No. 2, http://www.ecologyandsociety.org/vol14/iss2/art32/

Roscoe, P. (2014), I Spend, Therefore I am: The True Cost of Economics, Viking, London.

Rose, D.B. and Robin, L. (2004), "The ecological humanities in action: An invitation", Australian Humanities Review, available at: http://australianhumanitiesreview.org/2004/04/01/theecological-humanities-in-action-an-invitation/

Ruffing, L. (2007), "Silent vs. shadow reports: What can we learn from BP's sustainability report versus the financial times?", Social and Environmental Accountability Journal, Vol. 27 No. 1, pp. 9-16.

Russell, S. L. and Frame, B. (2013), "Technologies for sustainability: a governmentality perspective", International Journal of Sustainable Development, Vol. 16 No. 1, pp. 91-106.

Russell, S., and Lewis, L. (2014), "Accounting and accountability for fresh water", in Sustainability Accounting and Accountability, Bebbington, J., Unerman, J. and O'Dwyer, B. (eds.) Routledge, London, pp. 213-229.

Sachs, W. (1999), Planet Dialectics: Explorations in Environment and Development, Zed Books, Vauxhall, London.

Samkin, G., and Schneider, A. (2010), "Accountability, narrative reporting and legitimation: the case of a New Zealand public benefit entity", Accounting, Auditing \& Accountability Journal, Vol. 23 No. 2, pp. 256-289.

Samkin, G., Schneider, A., and Tappin, D. (2014), "Developing a reporting and evaluation framework for biodiversity", Accounting, Auditing \& Accountability Journal, Vol. 27 No. 3, pp. 527-562.

Samuelsson, L. (2010), "Environmental pragmatism and environmental philosophy: A bad marriage", Environmental Ethics, Vol. 32 No. 4, pp. 405-415.

Sandel, M. J. (2012), What Money Can't Buy: The Moral Limits of Markets, Macmillan, London.

Sayers, J. G. (2016), "A report to an academy: On carnophallogocentrism, pigs and meat-writing", Organization, Vol. 23 No. 3, pp. 370-386.

Scott, M. B. and Lyman, S. (1968), "Accounts", American Sociological Review, Vol. 33 No. 1, pp. 4662.

Sender, R., Fuchs, S., and Milo, R. (2016), "Revised Estimates for the Number of Human and Bacteria Cells in the Body", PLoS Biology, Vol. 14 No. 8, e1002533, https://doi.org/10.1371/journal.pbio.1002533

Shearer, T. (2002), "Ethics and accountability: from the for-itself to the for-the-other", Accounting, Organizations and Society, Vol. 27 No. 6, pp. 541-573.

Shepherd, N. (1934), In the Cairngorms, 2nd edition, 2015, Galileo Publishers, Plymouth, England.

Shepherd, N. (1977), The Living Mountain, Canongate, UK, (Re-issue edition, 2011).

Simmons, I. G. (2013), Interpreting Nature: Cultural Constructions of the Environment, Routledge, London.

Singer, P. (1995), Animal liberation, Random House, London.

Solomon, J. F. and Solomon, A. (2006), "Private social, ethical and environmental disclosure", Accounting, Auditing \& Accountability Journal, Vol. 19 No. 4, pp. 564-591. 
Spence, C. (2009), "Social accounting's emancipatory potential: a Gramscian critique", Critical Perspectives on Accounting, Vol. 20 No. 2, pp. 205-227.

Steffen, W., Richardson, K., Rockström, J., Cornell, S.E., Fetzer, I., Bennett, E.M., Biggs, R., Carpenter, S.R., de Vries, W., de Wit, C.A., Folke, C., Gerten, D., Heinke, J., Mace, G.M., Persson, L.M., Ramanathan, V., Reyers, B. and Sorlin, S. (2015), "Planetary boundaries: Guiding human development on a changing planet", Science, Vol. 347 No. 6223, pp. 1259855-1259855.

Stone, C. D. (1972), "Should Trees Have Standing--Toward Legal Rights for Natural Objects", Southern California Law Review, Vol. 45, pp. 450-501.

Stone, D. A. (1989), "Causal stories and the formation of policy agendas", Political Science Quarterly, Vol. 104 No. 2, pp. 281-300.

Sukhdev, P. W., Schröter-Schlaack, H., Nesshöver, C., Bishop, C., and Brink, J. (2010), The economics of ecosystems and biodiversity: mainstreaming the economics of nature: a synthesis of the approach, conclusions and recommendations of TEEB (No. 333.95 E19), UNEP, Geneva.

Sullivan, S. (2014), "The natural capital myth; or will accounting save the world? Preliminary thoughts on nature, finance and values", Leverhulme Centre for the Study of Value, Working Paper Series No. 3.

Sullivan, S. and Hannis, M. (2017), "'Mathematics maybe, but not money': on balance sheets, numbers and nature in ecological accounting", Accounting, Auditing \& Accountability Journal, this issue.

SustainAbility. (2006), Global Reporters 2006 Report Assessment Methodology, http://sustainability.com/our-work/reports/global-reporters-2006/ accessed 16 June 2017.

Szerszynski, B, Heim, W and Waterton, C. (2003), Nature Performed: Environment, Culture and Performance, Blackwell, London.

Tello, E., Hazelton, J. and Cummings, L. (2016), “Potential users' perceptions of general purpose water accounting reports", Accounting, Auditing \& Accountability Journal, Vol. 29 No 1, pp. 80-110.

Thévenot, L., Moody, M., and Lafaye, C. (2000), "Forms of valuing nature: arguments and modes of justification in French and American environmental disputes", in Rethinking comparative cultural sociology: Repertoires of evaluation in France and the United States, Lamont, M. and Thévenot, L. (eds.), CUP: Cambridge, pp. 229-272.

Thomson, I., Dey, C. and Russell, S. (2015), "Activism, arenas and accounts in conflicts over tobacco control", Accounting, Auditing \& Accountability Journal, Vol 28 No. 5, pp. 809-845.

Thomson, I., Grubnic, S. and Georgakopoulos, G. (2014), "Exploring accounting-sustainability hybridisation in the UK public sector", Accounting, Organizations and Society, Vol 39 No. 6 , pp. 453-476.

Thoreau, H.D., (1854), Walden (A Fully Annotated Edition, Cramer, J. (ed.), Yale University Press, 2004).

Thorslund, C. A., \& Lassen, J. (2016), "Context, Orders of Worth, and the Justification of Meat Consumption Practices", Sociologia Ruralis, in press.

Tilt, C. A. (1994), "The influence of external pressure groups on corporate social disclosure: some empirical evidence", Accounting, Auditing \& Accountability Journal, Vol. 7 No. 4, pp. 47-72.

Tilt, C.A., (2007), "External Stakeholders' Perspectives on Sustainability Reporting, in Sustainability Accounting and Accountability, Unerman, J., O'Dwyer, B and J. Bebbington (eds.), Routledge, London, pp. 104-126.

Tregidga, H. (2017), "'Speaking truth to power": analysing shadow reporting as a form of shadow accounting", Accounting, Auditing \& Accountability Journal, Vol. 30 No. 3, pp. 510-533.

Tregidga, H., Milne, M. J., and Kearins, K. (2015), "Ramping up resistance: Corporate sustainable development and academic research", Business \& Society, available online.

Trucost. (2017), https://www.trucost.com/ accessed 13 June 2017.

Turner, B. (2010), Untitled. Speech at Reflections on Water, Sunday 13 June, Christchurch, New Zealand https://www.ourwaterourvote.org.nz/actions-we-can-take/past-events/reflectionson-water/, accessed 15 June 2017.

Unerman, J., and Bennett, M. (2004), "Increased stakeholder dialogue and the internet: towards greater corporate accountability or reinforcing capitalist hegemony?", Accounting, Organizations and Society, Vol. 29 No. 7, pp. 685-707.

Vinnari, E., \& Dillard, J. (2016), "(ANT) agonistics: Pluralistic politicization of, and by, accounting and its technologies", Critical Perspectives on Accounting, Vol. 39, pp. 25-44. 
Waistell, J. (2016), “Can Environmental Aesthetics Promote Corporate Sustainability?", Organization \& Environment, Vol. 29 No. 2, pp. 175-193.

Waters, C.N., Zalasiewicz, J., Summerhayes, C., Barnosky, A.D., Poirier, C., Gałuszka, A., Cearreta, A., Edgeworth, M., Ellis, E.C., Ellis, M., Jeandel, C., Leinfelder, R., McNeill, J.R., Richter, D.D., Steffen, W., Syvitski, J., Vidas, D., Wagreich, M., Williams, M., Zhisheng, A., Grinevald, J., Odada, E., Oreskes, N. and Wolfe, A.P. (2016) "The Anthropocene is functionally and stratigraphically distinct from the Holocene", Science, Vol. 351 No. 6269, pp. aad2622.

Waterton, C. A. (2003), "Performing the classification of nature", in B. Szerszynski, W. Heim and C. A. Waterton (eds.), Nature performed: environment, culture and performance, Blackwell, Oxford, pp. 111-129.

Wesselink, A., Buchanan, K. S., Georgiadou, Y., and Turnhout, E. (2013), "Technical knowledge, discursive spaces and politics at the science-policy interface", Environmental Science \& Policy, Vol. 30, pp. 1-9.

(WET) Waihora Ellesmere Trust (2015), Te Waihora/Lake Ellesmere State of the Lake Report 2015, available at: http://www.wet.org.nz/projects/2015-state-of-the-lake/ accessed 2 July 2017.

Wezel, A., Bellon, S., Doré, T., Francis, C., Vallod, D., and David, C. (2009), “Agroecology as a science, a movement and a practice: A review", Agronomy for Sustainable Development, Vol. 29 No. 4, pp. 503-515.

Whatmore, S. (2006) "Materialist returns: practising cultural geography in and for a more-thanhuman world", Cultural Geographies, 13(4), pp. 600-609.

Whatmore, S. (2009), "Nature", in Gregory, D., The dictionary of human geography, Blackwell Publishers, Oxford.

Whatmore, S.J. (2013) "Earthly Powers and Affective Environments: An Ontological Politics of Flood Risk", Theory, Culture \& Society, 30(7-8), pp. 33-50.

Whatmore, S.J. and Landström, C. (2011), "Flood apprentices: an exercise in making things public", Economy and Society, Vol. 40 No. 4, pp. 582-610.

Whiteman, G. (2010), "“First You Have To Get Outside": Reflecting on the Ecological Location of Qualitative Research", Organization \& Environment, Vol. 23 No. 2, pp. 119-131.

Whiteside, K. H. (2002), Divided Natures: French Contributions to Political Ecology, MIT Press, Boston, MA.

Williams, R. (1976), Keywords: A Vocabulary of Culture and Society, Oxford University Press, New York.

\section{Recommended reading}

Bekoff, M. (2014), Rewilding Our Hearts: Building Pathways of Compassion and Coexistence. New World Library, Novato, California.

Boltanski, L. and Thévenot, L. (2006), On Justification: Economies of Worth. Princeton University Press, Princeton, New Jersey.

Castree, N. (2013), Making Sense of Nature, Routledge, London.

Cox, R. (2012), Environmental Communication and the Public Sphere, Sage publications, Thousand Oaks, CA.

Jamie, K. (2012), Sightlines: A Conversation with the Natural World, Sort of Books, London.

Monbiot, G. (2014), Feral: Rewilding the Land, the Sea, and Human Life, University of Chicago Press, Chicago.

Simmons, I. G. (2013), Interpreting Nature: Cultural Constructions of the Environment, Routledge, London.

Szerszynski, B., Heim, W. and Waterton, C. (2003), Nature Performed: Environment, Culture and Performance, Blackwell, Oxford. 
Table 1: Boltanski and Thévenot's (2006) "Seven Orders of Worth"

\begin{tabular}{|c|c|c|c|c|c|c|c|}
\hline & Market & Industrial & Civic & Domestic & Inspired & Opinion & Green \\
\hline $\begin{array}{l}\text { Mode of evaluation } \\
\text { (worth) }\end{array}$ & Price, cost & Technical efficiency & Collective welfare & $\begin{array}{l}\text { Esteem, } \\
\text { reputation }\end{array}$ & $\begin{array}{l}\text { Grace, singularity, } \\
\text { creativeness }\end{array}$ & Renown, fame & $\begin{array}{l}\text { Environmental } \\
\text { friendliness }\end{array}$ \\
\hline Test & $\begin{array}{l}\text { Market } \\
\text { competitiveness }\end{array}$ & $\begin{array}{l}\text { Competence, } \\
\text { reliability, planning }\end{array}$ & $\begin{array}{l}\text { Equality and } \\
\text { solidarity }\end{array}$ & Trustworthiness & $\begin{array}{l}\text { Passion, } \\
\text { enthusiasm }\end{array}$ & $\begin{array}{l}\text { Popularity, } \\
\text { audience, } \\
\text { recognition }\end{array}$ & $\begin{array}{l}\text { Sustainability, } \\
\text { renewability }\end{array}$ \\
\hline $\begin{array}{l}\text { Form of relevant } \\
\text { proof }\end{array}$ & Monetary & $\begin{array}{l}\text { Measurable: } \\
\text { criteria, statistics }\end{array}$ & Formal, official & $\begin{array}{l}\text { Oral, exemplary, } \\
\text { personally } \\
\text { warranted }\end{array}$ & $\begin{array}{l}\text { Emotional } \\
\text { involvement \& } \\
\text { expression }\end{array}$ & Semiotic & $\begin{array}{l}\text { Ecological, } \\
\text { Ecosystemic }\end{array}$ \\
\hline Qualified objects & $\begin{array}{l}\text { Freely circulating } \\
\text { market good or } \\
\text { service }\end{array}$ & $\begin{array}{l}\text { Infrastructure, } \\
\text { project, method, } \\
\text { plan }\end{array}$ & $\begin{array}{l}\text { Rules \& regulations, } \\
\text { fundamental rights }\end{array}$ & $\begin{array}{l}\text { Patrimony, } \\
\text { locale, heritage }\end{array}$ & $\begin{array}{l}\text { Emotionally } \\
\text { invested body or } \\
\text { item; the sublime }\end{array}$ & Sign, media & $\begin{array}{l}\text { Pristine wilderness, } \\
\text { ecosystem health, } \\
\text { natural habitat }\end{array}$ \\
\hline $\begin{array}{l}\text { Qualified human } \\
\text { beings }\end{array}$ & $\begin{array}{l}\text { Customer, } \\
\text { consumer, } \\
\text { merchant, seller }\end{array}$ & $\begin{array}{l}\text { Engineer, } \\
\text { professional, } \\
\text { expert }\end{array}$ & $\begin{array}{l}\text { Equal citizens, } \\
\text { solidarity unions }\end{array}$ & Authority & Creative being & Celebrity & Environmentalist \\
\hline Time formation & $\begin{array}{l}\text { Short-term, } \\
\text { flexibility }\end{array}$ & $\begin{array}{l}\text { Long-term planned } \\
\text { future }\end{array}$ & Perennial & Customary past & $\begin{array}{l}\text { Eschatological, } \\
\text { revolutionary, } \\
\text { visionary moment }\end{array}$ & Vogue, trend & Future generations \\
\hline Space formation & Globalization & Cartesian space & Detachment & $\begin{array}{l}\text { Local, proximal } \\
\text { anchoring }\end{array}$ & Presence & $\begin{array}{l}\text { Communication } \\
\text { network }\end{array}$ & Planet ecosystem \\
\hline
\end{tabular}

Source: Adapted from Thévenot et al. (2000, p. 241). 
In June 2010, around 4,000 people gathered in Cathedral Square on a cold, grey Saturday to attend the 'Reflections on Water' event[27]. Campaigners gathered to protest against the appointment of environmental commissioners to the regional council and express concern about the management of the region's water resources. People passed stones along the line, some marked with names of rivers creating a cairn (see Figure 1). The plaque read:

In order to advance the massive irrigation schemes proposed for the Canterbury plains the hard-won conservation orders on our best rivers have been disestablished and our right of appeal to the environment court have been removed. Indeed, Cantabrians are now subject to laws separate from any other province of our country. This is a clear breach of the bill of rights and the principles of natural justice. The cairn is constructed of boulders from the Waimakariri river whose endangered waters are silently moving beneath your feet. It is the wish of the people who laid these stones that they remain here until democracy entire is returned to us.

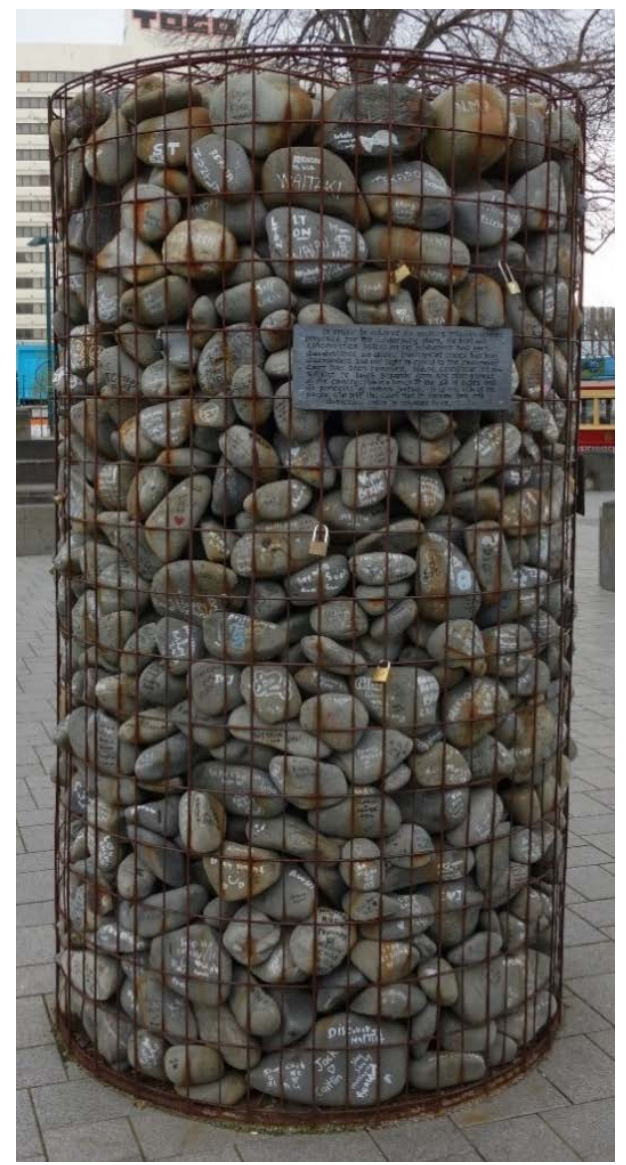

Figure 1: Mahon's stone cairn by Schwede66

(https://commons.wikimedia.org/wiki/File:Mahon\%27s stone cairn_010.jpg) is licensed by Creative Commons Attribution-Share Alike 4.0 International license.

Political leaders, activists and artists gave speeches. Brian Turner, poet laureate (2003-5) observed [28]:

One of the most distinctive and naturally appealing things about the south's landscapes is that they're not all an artificially-produced vivid green, and nor should they be. We don't have a God-given right, nor duty, to modify and convert everything in nature to suit our perceived present-day requirements. Which is why there's a desperate need to convince the wider public that watertight environmental protection is an urgent priority and a major long-term benefit, not a cost, to society as a whole.

Up until, say, around the mid-eighties, nearly all the rivers and streams between Dunedin and Christchurch were fairly clean and healthy; nearly all had a decent flow in them. But in the last 20 years especially, what has happened to the rivers and streams within, say, an hour's drive from Christchurch, is tragic and deeply wrong. It is wrong when opportunistic private interests in effect steal, or look to steal, what rightfully belongs to the public.

Box 1: An account of an environmental campaign 


\section{End Notes}

${ }^{1}$ The term 'the Anthropocene' was first coined in 1999 by Paul Crutzen as way term to suggest that "human actions have become the main driver of global environmental change" (Rockström et al., 2009, p. 1).

${ }^{2}$ According to cultural critic Raymond Williams, nature is one of the "most complex and contested terms in the English language" (Williams, 1976, p. 221). Nature can also denote that which is (i) external - 'out there' and unmediated by humans; (ii) intrinsic - something's essential characteristics; or (iii) universal - an allencompassing force controlling things in the world (Castree, 2005; Ginn and Demeritt, 2008; Whatmore, 2009). Efforts to dissolve human-nature dualisms have led to the development of nomenclature to convey the dynamic, emergent and contingent, and interconnected qualities of worlds (Szerzynski et al., 2003). For example, socionatures (Castree and Braun, 2001); nature(s)-beyond-human (Sullivan and Hannis, 2017) and more-thanhuman worlds (Abram, 1997; Gibbs, 2009; Whatmore, 2006). In this paper, we refer to human-nature relations and human-non-human relations as interchangeable terms.

${ }^{3}$ Drawing upon post-colonial studies, Howitt and Suchet-Pearson (2006) call on those working in the fields of environmental policy, management and governance, including researchers, to critically examine and reflect on the assumptions upon which disciplines are founded arguing that they are founded on Eurocentric views of nature and human-nature relations.

${ }^{4}$ Blanket bog or blanket mire, also known as featherbed bog, is an area of peatland, forming where there is a climate of high rainfall and a low level of evapotranspiration, allowing peat to develop not only in wet hollows but over large expanses of undulating ground.

${ }^{5}$ Three events were held in 2014 and 2015 at international social and environmental accounting and critical management conferences to support the development of potential papers. Twenty-three sets of authors presented over thirty papers during these events demonstrating the diverse array of work underway concerning socio-ecological change.

${ }^{6}$ Indeed, recent scientific work estimates humans are a little less than half human cells, and a little more than half bacteria cells (Sender et al., 2016).

${ }^{7}$ Canterbury is one of the largest dairy producing regions in New Zealand with a long history of debates about the management of the region's land and water resources. The research programme (2008-2011) examined initiatives to address complex and contested water management issues (Lennox et al., 2011; Russell and Frame, 2013). Public campaigns such as the one described here were documented to understand the context in which government-led initiatives were being designed and implemented.

${ }^{8}$ Agroecology is a practice and social movement that aims to improve agricultural productivity and conserve natural resources (Wezel et al., 2009). Rejecting the use of chemical fertilisers, agroecology involves the creation of habitats using other flora and fauna alongside cultivated plants, which then effectively become providers of local ecosystems services (including pest control, pollination and carbon capture as well as soil sustenance).

${ }^{9}$ See, for example, Deegan (2017), Gray (2002a; 2002b; 2010a; 2010b), Hopwood (2009), Mathews (1984; 1997), Milne (2007; 2013), Owen (2008), and Parker (2005; 2011).

${ }^{10}$ These include Green Accounting (Gray and Laughlin, 1991 - see also the follow up re-evaluation by Gray and Laughlin 2012); Engagement and Social \& Environmental Accounting (Adams and Larrinaga-González, 2007); Sustainability Accounting (Burritt and Schaltegger, 2010); Climate Change and GHG Accounting (Milne and Grubnic, 2011); Accounting for Biodiversity (Jones and Solomon, 2013); and Accounting for Extinction (Atkins and Maroun, forthcoming).

${ }^{11}$ It is worth noting, however, that some of this early work was also focused on macro socio-economic accounts, and so a broader context than (micro-level) organisational social accounting, e.g. Estes (1972), Gambling (1974), Ramanathan (1976), and Mathews (1984).

${ }^{12} \mathrm{See}$, for example, the considerable critical literature on the 'neoliberalisation of nature' (e.g. Büscher et al., 2014; Castree, 2008a; 2008b; Heynen and Robbins, 2005).

13 These impact bonds differ from the more 'conventional' green and climate bonds issued by large financial institutions and corporations (Climate Bonds Initiative, 2016) in that they are better understood as a form of 'payment by results', in which investors provide upfront funding for a project, with the initial investment plus a further return being repaid to them if a set of pre-defined outcome targets are met by the service provider.

${ }^{14}$ See, for example, Bayon and Jenkins (2010), BBOP (2012), Bull et al. (2013), Maron et al. (2012).

${ }^{15}$ Gambling (1974), in fact, drawing on Mattessich's (1964) core "axioms of accounting" practice (e.g. monetary values, time intervals, aggregation, economic transactions, economic objects, entities) demonstrates just how resistant the accounting model is to modification.

${ }^{16}$ As will become clear in section 5, this dominant framing locates the environment within Luc Boltanski and Laurent Thévenot's "Market" and "Industrial" orders of worth as to its value, thereby offering a narrow and particular justification.

${ }^{17}$ Early external accounts by Social Audit Ltd. and Counter Information Services (CIS) are also reminiscent of the early consumer protection and environmental activities of groups like Nader's raiders. Ralph Nader is an American trained lawyer who came to fame for his 1965 publication Unsafe at any Speed - an investigation into 
car safety design at General Motors. He later formed Ralph Nader's study group of legal interns and activists (dubbed Nader's Raiders) to investigate a multitude of public interest issues and produce reports. Such reports, which led to significant legal reform and consumer and environmental protective legislation in the United States provides a stunning example of effective investigatory research and counter accounts.

${ }^{18}$ The Tasman Pulp and Paper mill has polluted the Tarawera River since 1955 when it was built with its operations protected by a specific statute of law. In 1991 the Resource Management Act required such pollution to be subject to resource consents and thus it came to be subject to public consultation. Greenpeace NZ campaigned for years against Fletcher Challenge Ltd. the parent company. The mill was sold in 2000 to Norske Skog, a Norwegian paper conglomerate, and in 2009, despite continuing Maori hostility and a court case, it was granted a further 25 -year consent to continue discharging pollutants.

${ }^{19}$ Also see, for example, Beder (2002), Cox (2012), and Lubbers (2002).

${ }^{20}$ As of 2017, the mine has not proceeded, and a subsequent group (Biodiversity Defence Society) has filed for an Environment Court declaration that the mining resource consents have expired and are no longer valid.

${ }^{21}$ Also see Perkiss and Tweedie (2017) on identifying potential moral sources to motivate social and ecological concern, and Lehman (2017) and Waistell (2016) on the potential of evocative language and aesthetics to promote similar engagement.

${ }^{22}$ Similar to 'collective action frames', causal stories play strategic roles for social movement organisations by inspiring action, and legitimating a group's claims. They also clearly form part of the science-policy interface, and consequently inform contests over articulations of nature. See, for example, Buchanan (2013), Nelson and Willey (2001), Reber and Berger (2005), and Wesselink et al. (2013).

${ }^{23}$ Thévenot et al. (2000, p. 238-239) express the point they are concerned with "...examining the pragmatics of public space and discourse through an analysis of a plurality of regimes of action". In doing so they see parallels with Habermas' (1984) theory of communicative action and Arendt's (1958) theory of political action.

${ }^{24}$ As Blok (2013, p. 16, emphasis in original) puts it “...ecology is not just a matter of plural value orders [as represented by the other six orders]; rather ecology itself emerges as a world of inherent moral and cognitive tensions... political ecology is a less coherent, more internally varied, and more morally diverse ensemble of projects... Learning to differentiate senses of green worth, and to apply their justifications and critiques according to situational opportunities, would then be an important task for both practical and theoretical work." Of course, anyone familiar with the diverse array of stands of environmentalism (e.g. Dryzek, 1997; Lewis, 1994) and the contested ethical debates of the eco-centrism/anthropocentrism divide (e.g.; Callicott, 1984; 1989; Eckersley, 1992; Gough et al., 2000; Norton, 1994; Whiteside, 2002) would not be surprised by this. A particular strand of this work that has sought to move away from the 'theoretical impasse' and study environmental values 'on the ground' and in 'concrete cases' is environmental pragmatism (e.g. Katz and Light, 2013; Norton, 1999; Samuelsson, 2010). Consequently, we see some potential in exploring the overlap between environmental pragmatism, and the pragmatic sociology of Latour, Boltanski and Thévenot for informing accounts of nature(s). ${ }^{25}$ See, for example, Eckersley (1992), Midgley (1998), Nash (1989), Singer (1995), and Stone (1972).

${ }^{26}$ There is an exquisite video "How Wolves Change Rivers" (https://vimeo.com/86466357) narrated by George Monbiot that recounts the ecological impact of the reintroduction of wolves to Yellowstone National Park. It illustrates how "trophic cascades" in a series of causal links and webs occurred changing biotic populations of animals and plants and ultimately the physical geography of the rivers.

${ }^{27}$ The event was organised by the Our Water, Our Vote campaign (www.ourwaterourvote.co.nz) Accessed 5 June 2017. Campaigners also wrote letters to the press and public meetings on the same topic.

${ }^{28}$ https://www.ourwaterourvote.org.nz/uploads/Brian\%20Turner\%20\%20Talk\%20for\%200ur\%20Water\%200ur\%20Vote.pdf (accessed 15 June 2017). 